\title{
White Paper Powering Sustainable Low-Carbon Economies: Some Facts and Figures
}

Gilles J. Youinou

April 2015

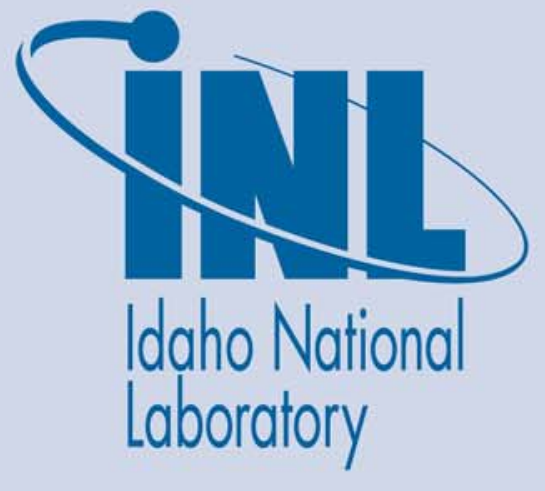

The INL is a U.S. Department of Energy National Laboratory operated by Battelle Energy Alliance 
INL/EXT-15-34911

\section{White Paper \\ Powering Sustainable Low-Carbon Economies: Some Facts and Figures \\ Gilles J. Youinou}

April 2015

Idaho National Laboratory

Idaho Falls, Idaho 83415

http://www.inl.gov

Prepared for the

U.S. Department of Energy

Office of Nuclear Energy

Under DOE Idaho Operations Office

Contract DE-AC07-05ID14517 


\section{White Paper}

\section{Powering Sustainable Low-Carbon Economies: Some Facts and Figures}

Gilles J. Youinou
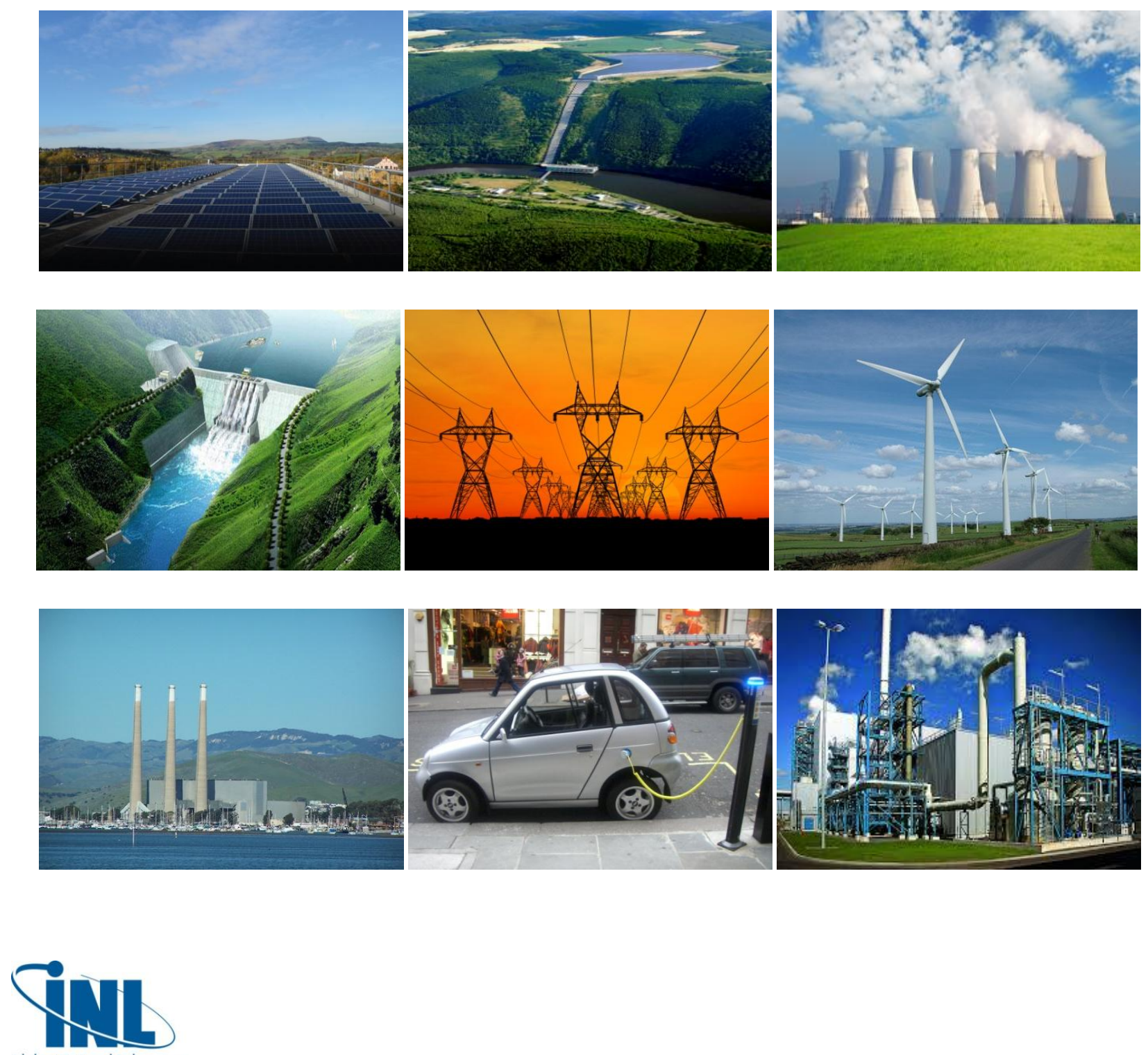

Idaho National Laboratory The INL is a U.S. Department of Energy National Laboratory operated by Battelle Energy Alliance 


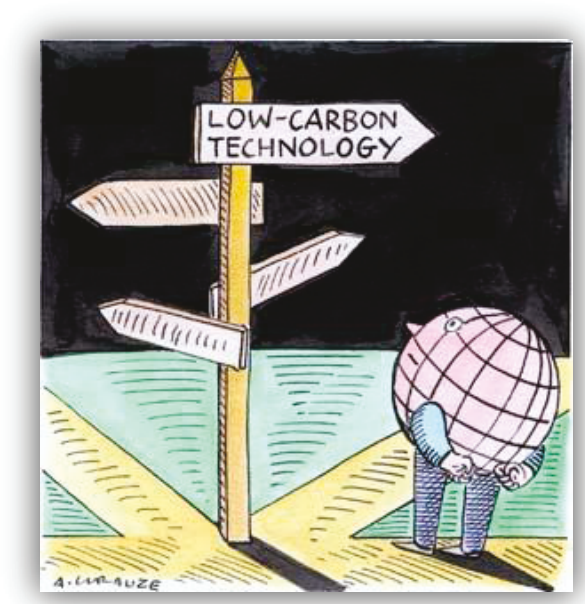

Source: http://www.worldchanging.com/

"Most people overestimate what they can do in one year and underestimate what they can do in ten years." - Bill Gates 


\section{Content}

Summary

1. Introduction and background

2. Coal and gas power plants

3. Wind and solar power plants

4. Nuclear power plants

5. Cost considerations

6. Risk considerations

7. Conclusions

8. References 
The latest report from the Intergovernmental Panel on Climate Change urges that global $\mathrm{CO} 2$ emissions from the power sector should be reduced by 90 percent or more below 2010 levels between 2040 and 2070. Such a reduction will most likely require greatly increasing the share of wind, solar, energy storage and nuclear energy in the energy mix in the next 40 to 50 years. This paper emphasizes the importance of developing large energy storage systems without which, wind and solar can only have a limited impact on $\mathrm{CO} 2$ emissions as it will depend mainly on the energy mix used during wind and solar down time. The large areas that are required would be challenging but not unrealistic as long as a solution for energy storage exists. Carbon capture and storage has considerable potential to reduce $\mathrm{CO} 2$ emissions from coal and gas power plants but also from heavy industries such as cement and steel manufacturing. To give an idea of the scale of the required infrastructure, in the United States, coal and gas power plants emit approximately 2.4 billion tonnes of $\mathrm{CO} 2$ per year whereas the US annual petroleum consumption is about 0.9 billion tonnes (6.9 billion barrels). This paper also emphasizes that uranium and thorium used in breeder reactors represent an almost infinite source of low-carbon energy. The issues associated with the management of nuclear wastes are real but they are not the uniquely difficult issues perceived by the media, much of the public and by many politicians. Severe nuclear accidents expose only very few people to high radiation doses but can on the other hand expose large populations to low radiation doses. Further research on the controversial effects of low radiation doses is crucial to reach a consensus on this matter because it has far reaching consequences such as on the decision to displace large populations following a nuclear accident for example. Finally, the investment necessary to implement a wind and solar powered economy would very likely be higher than that necessary to implement a nuclear powered economy because of the much larger number of GWe required.

\section{Keywords}

Renewable Energy, Nuclear Energy, Natural Resources, CO2 Emissions, Risks 


\section{Introduction and background}

In 2011, the world production of electricity was about 22.1 trillion kilowatt-hour $^{1}$ (kWh): 9.1 from coal, 4.8 from gas, 2.6 from nuclear, 1.1 from oil, 3.5 from hydropower and 1.0 from other sources (geothermal, solar, wind, biofuels). With a world population of about 7 billion in 2011, it corresponds to an average of 3,160 kWh per year and per person. While most industrialized countries enjoy a high standard of living with, at least, $8,000 \mathrm{kWh}$ per year and per person, most people in developing countries live with less than $3,000 \mathrm{kWh}$ per year. The need for electricity is growing fast, especially in developing countries, and by 2040 the world production of electricity is projected to reach about 40 trillion $\mathrm{kWh}^{2}$ Assuming a world population of 10 billion and an average consumption of $6,000 \mathrm{kWh}$ per year per person in 2100 the world annual production of electricity could reach 60 trillion $\mathrm{kWh}$.

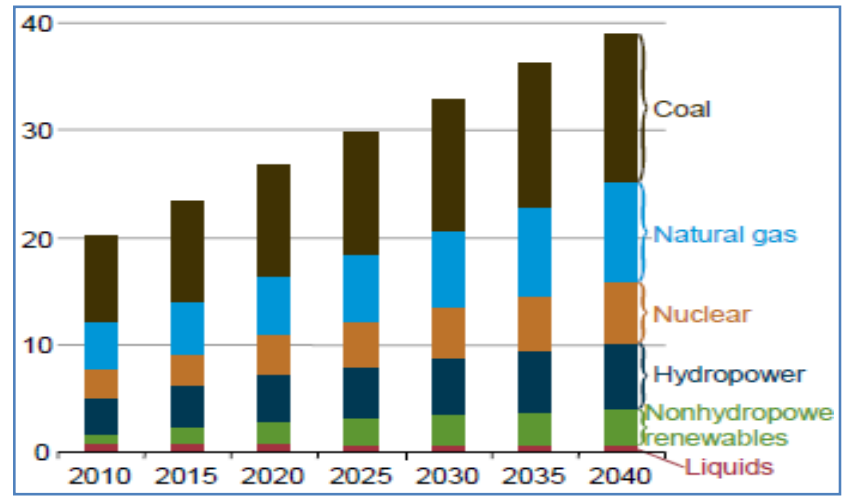

A possible scenario to cope with the expected increased electricity demand. Source: U.S. Energy Information Administration, "International Energy Outlook 2013"

In 2011, the world emitted about 31 billion tonnes of $\mathrm{CO} 2$ in the atmosphere. ${ }^{3}$ With 42 percent of the total, the power sector was the largest emitter, followed by transport and industry (respectively 22 and 21 percent). To limit the increase in temperature due to $\mathrm{CO} 2$ emissions to no more than $2^{\circ} \mathrm{C}$ by 2100 , the latest Intergovernmental Panel on Climate Change (IPCC) report urges that $\mathrm{CO} 2$ emissions from the power sector should be reduced by 90 percent or more below 2010 levels between 2040 and 2070. ${ }^{4}$ The evolution of the emissions from the power sector will strongly depend on the technologies used to generate electricity, i.e. fossil, nuclear or renewables, as well as on the level of implementation of carbon capture and storage (CCS) technologies. Three particular uses of electricity may increase significantly in the near future: electric and/or hydrogen powered cars in order to decarbonize part of the transportation system and desalination of saline water.

The number of passenger cars in the world is currently estimated at around 1 billion and is expected to grow to at least 2 billion by $2050 .^{5} \mathrm{~A}$ typical electric car requires about 0.3 $\mathrm{kWh}$ per mile; ${ }^{6}$ hence, assuming 1 billion passenger plug-in electric vehicles on the road in 2050, each driving 20 miles a day, the energy requirement would be of the order of 2.2 trillion $\mathrm{kWh}$ per year. Given that typical hydrogen powered passenger cars will require between 0.013 and $0.02 \mathrm{~kg}$ of hydrogen per mile ${ }^{7}$ and that the production of hydrogen by water elec- 
trolysis requires between 35 and $50 \mathrm{kWh}$ per $\mathrm{kg}$ of hydrogen, ${ }^{7,8}$ it is concluded that hydrogen cars will require (indirectly) between 0.5 and $1.0 \mathrm{kWh}$ per mile. The same 1 billion cars as mentioned above (powered by hydrogen) would require between 3.65 and 7.3 trillion $\mathrm{kWh}$ per year. Note that since improvements in the efficiency of regular internal combustion engines will likely bring average $\mathrm{CO} 2$ emissions down to values as low as $150 \mathrm{~g} / \mathrm{mile}$ by $2025,{ }^{9,10}$ the electricity necessary to charge the batteries or produce hydrogen will need to come from carbon-free energy sources (renewable, nuclear or fossil with CCS) for the electric or hydrogen cars to make a difference on $\mathrm{CO} 2$ emissions. Indeed, if the electricity comes from gas power plants without CCS, the electric and hydrogen cars would be responsible for, respectively, 150 and 250 to $500 \mathrm{~g}-\mathrm{CO} 2 / \mathrm{mile}$. With coal power plants these numbers would be doubled.
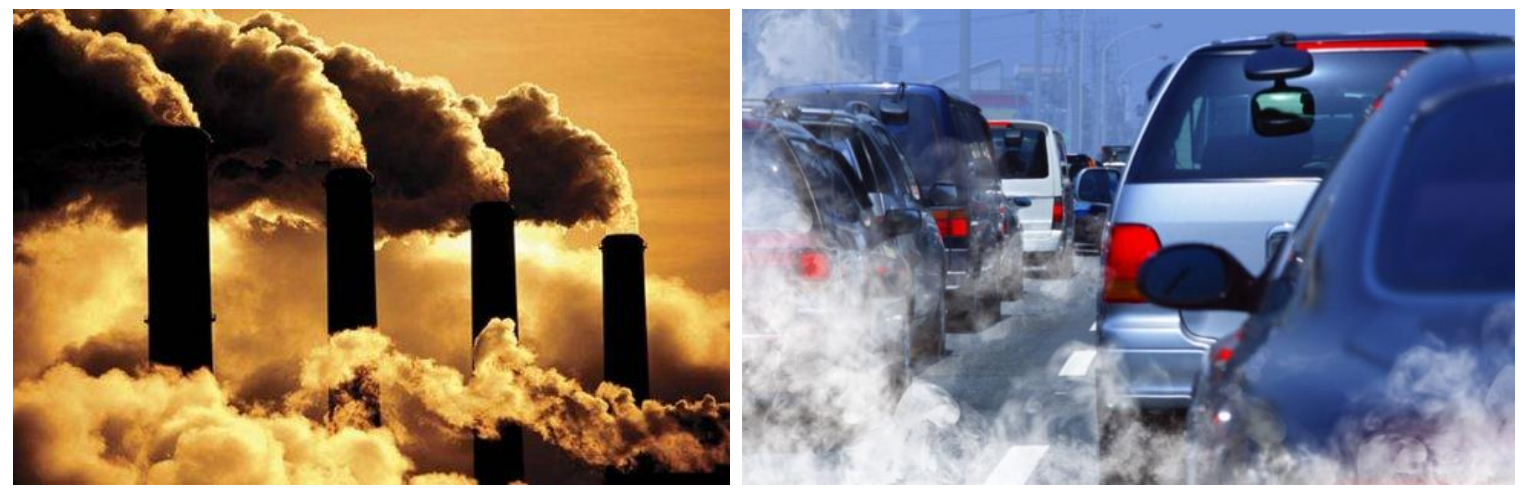

Production of electricity and transportation are currently responsible for most of the CO2 emissions.

By 2025, the United Nations anticipate that two-thirds of the world's population could be living in water stressed regions ${ }^{11}$ and, consequently, the use of desalination may increase significantly in the near future. Reverse Osmosis is currently the desalination process requiring the least amount of energy: typically $3-7 \mathrm{kWh}$ to produce 1 cubic meter of pure water from seawater and $0.5-3 \mathrm{kWh}$ from brackish water. ${ }^{12}$ If, let's say, 20 percent of the current 3 trillion cubic meters world annual water consumption ${ }^{13}$ were to be produced from saline waters it would require about 1.8 trillion $\mathrm{kWh}$ per year (assuming $3 \mathrm{kWh}$ per cubic meter).

The objective of this report is not to present an up-to-date picture of the world power sector but, instead, to present some facts and figures regarding the potential of different energy sources to contribute to a global sustainable low carbon power sector. Hence, for example, even though very relevant to a discussion on the power sector, the current difficulties experienced by the nuclear industry, caused in part by the very low price of natural gas, in some regions of the world are not analyzed. Section 2 presents some facts and figures concerning coal and gas resources, emissions and briefly presents challenges and opportunities associated to carbon capture and storage. Section 3 and 4 deal with the carbon-free technologies that should be greatly expanded if $\mathrm{CO} 2$ emissions are to be drastically reduced, i.e. wind, solar and nuclear. Section 5 and 6 consider, respectively, costs and risks. Finally Section 7 concludes this paper. 


\section{Coal and gas power plants}

Depending on the technology used, a typical $1 \mathrm{GWe}(=1$ million $\mathrm{kWe})$ coal-fired power plant producing 7 billion $\mathrm{kWh} /$ year (which corresponds to a typical capacity factor of 80 percent) burns about 2.5 to 3.5 million tonnes of coal and releases 5 to 7 million tonnes of $\mathrm{CO} 2$ each year. The values corresponding to most of the currently operating coal-fired power plants (subcritical) are in the upper end of the ranges provided above, whereas those corresponding to the newer, more efficient plants (supercritical) are in the lower end. ${ }^{14}$ A typical 1 GWe coal-fired power plant produces also between 250,000 and 350,000 tonnes of ash which contain several tonnes of toxic heavy metals ${ }^{15}$ such as arsenic (from a few grams per tonne up to 250 grams per tonne), lead (about the same range as arsenic) or selenium (2 to 20 grams per tonne). Assuming an ash density of between 0.75 and 1.5 tonne per cubic meter (depending on the degree of compaction of the ash), it represents a volume of 170,000 to 470,000 cubic meters per year, i.e. enough to fill the Pentagon building in Washington DC in about 3.5 to 9 years. Even though some of it is put to useful use such as for cement manufacturing, most of this ash is stored in ponds next to the plants and a common threat associated with coal waste management is the leaching of these heavy metals resulting in surface or groundwater contamination. ${ }^{16}$

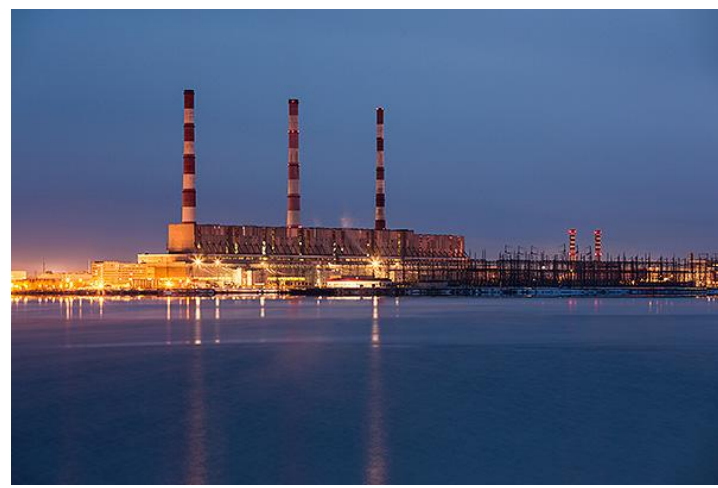

Surgut-2 gas-fired power plant (5.6 GWe), Russia

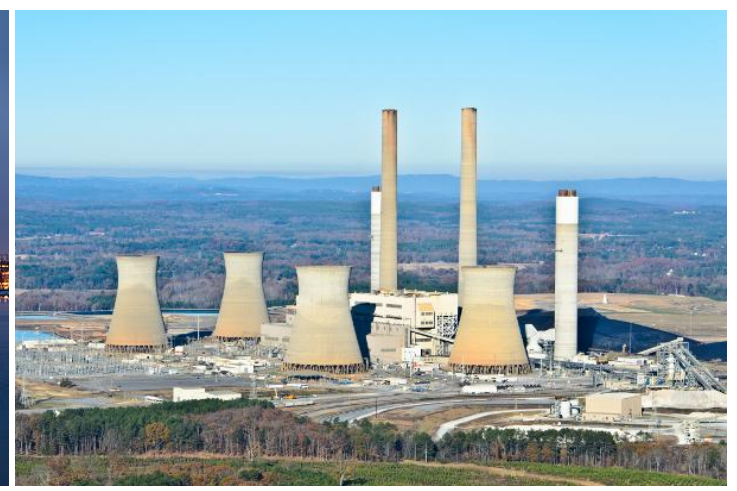

Bowen coal-fired power plant (3.5 GWe), USA

Source: http://www.power-technology.com/

Little known to the public, this ash also contains approximately 10 to 30 grams of uranium per tonne and a similar amount of thorium, ${ }^{17}$ hence the ash generated by a typical 1 GWe coal power plant contains between about 2.5 and 10.5 tonnes of uranium per year and a similar amount of thorium. To produce the same energy, a gas power plant burns on average about 1.2 million tonnes of gas (1.5 billion cubic meters STP) and releases about 3 to 3.5 million tonnes of $\mathrm{CO} 2$ with the advantage of not generating ashes. Replacing coal by gas in the near future is probably the most pragmatic and effective way of quickly reducing $\mathrm{CO} 2$ emissions in the power sector. ${ }^{18}$ Assuming an average consumption of about $8,000 \mathrm{kWh}$ per year, a person living in an industrialized country would be responsible for the release of about 6 to 8 tonnes of $\mathrm{CO} 2$ per year if the electricity came only from coal power plants and of about 4 tonnes of $\mathrm{CO} 2$ per year if the electricity came only from gas power plants. 
If the totality of the present world electricity production coming from coal, gas, oil and nuclear combined (17.6 trillion $\mathrm{kWh}$ ) came from coal power plants alone, the currently estimated 0.9 to 4.5 trillion tonnes of coal resources ${ }^{19}$ would last between 100 and 700 years if it was used only for electricity production (which is not the case; the power sector represents about 60 percent of coal consumption and the rest is used for industrial purposes such as cement manufacturing and steel production). Compared to the current situation, this would represent approximately a doubling of the production of electricity from coal. In the case of gas power plants, the currently estimated 210 to 550 trillion cubic meters of natural gas resources ${ }^{20}$ would last between 55 and 145 years if it was used only for electricity production (which is not the case either; the power sector represents only about 30 percent of natural gas consumption and the rest is used for heating, cooling and for other industrial applications). Compared to the current situation, this would represent an increase of the production of electricity from gas by a factor 3.7. Taking into account the many uses of natural gas for applications other than power production, it is very unlikely that such capacity increase could actually be sustained for more than 70 years. An application of coal that is currently only marginal but could increase significantly in the future is the conversion of coal into liquid fuel for the transport sector. Since it takes approximately $500 \mathrm{~kg}$ of coal to produce one barrel of diesel fue ${ }^{21}$ about 15 billion tonnes of coal (i.e. about twice the current coal consumption) would be necessary to replace the approximately 30 billion barrels of oil that were consumed worldwide in 2011.

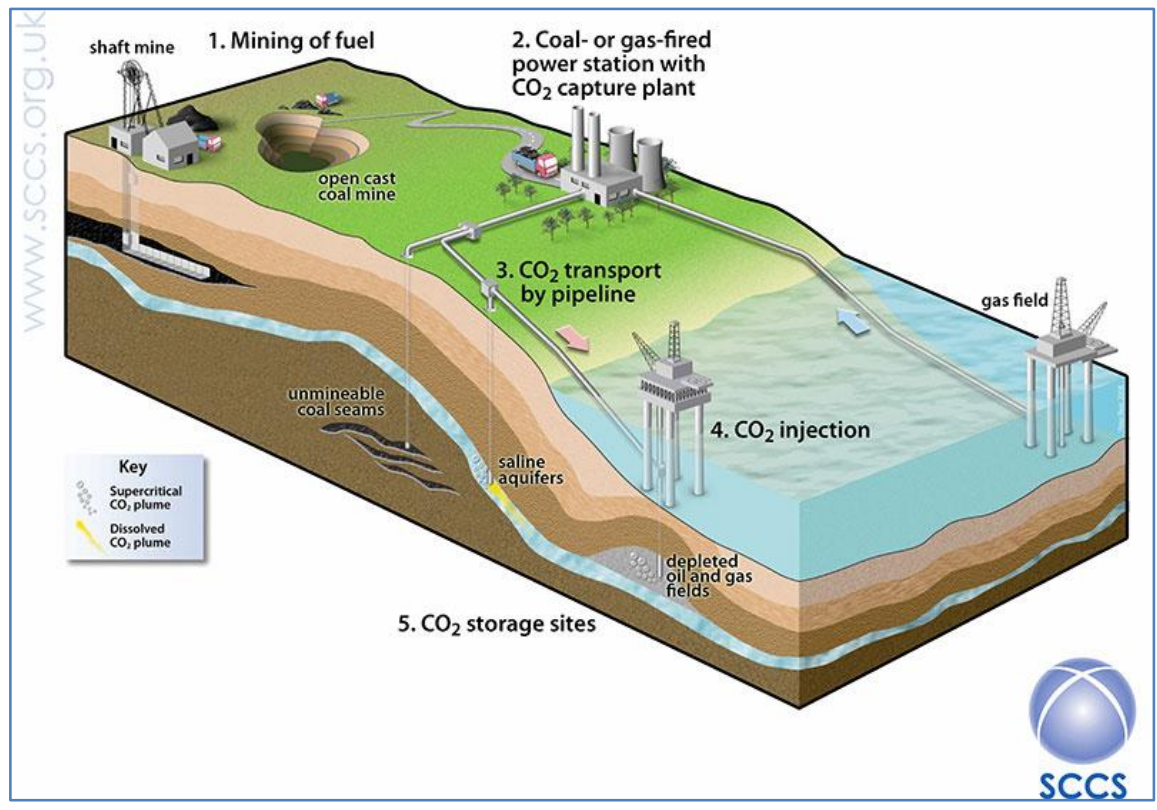

Carbone capture and storage process. Source: www.sccs.org.uk

Carbon capture and storage (CCS) has considerable potential to reduce $\mathrm{CO} 2$ emissions from coal and gas power plants but also from heavy industries such as cement and steel manufacturing. The required technologies already exist in various stages of development ${ }^{22}$, but on a much smaller scale, and the real challenge is to extrapolate (by about three orders of 
magnitude) and implement them fast enough, i.e. in the next 40-50 years, so that they have a meaningful impact on $\mathrm{CO} 2$ emissions in the timeframe recommended by the IPCC. CCS systems will have to be implemented on new power plants but also, on a case-by-case, on existing power plants. ${ }^{23}$ To give an idea of the scale of the required infrastructure, in the United States (US) coal and gas power plants emit approximately 2.4 billion tonnes of $\mathrm{CO} 2$ per year, which represents about 25 billion barrels (assuming a supercritical CO2 density of 600 $\mathrm{kg} / \mathrm{m}^{3}$ ), whereas the US annual petroleum consumption is about 6.9 billion barrels, i.e. about 0.9 billion tonnes. These numbers highlight that, if implemented, CCS will be a very large industry. It should also be fully operational in the next 40-50 years to make a difference on $\mathrm{CO} 2$ emissions.

As mentioned above, various $\mathrm{CO} 2$ capture technologies already exist but they require approximately 30 percent of the power of the plant (i.e. a $1 \mathrm{GWe}$ power plant would be able to deliver only $0.7 \mathrm{GWe}$ to the grid whereas $0.3 \mathrm{GWe}$ would be used to capture $\mathrm{CO} 2$ ), and are also very costly. ${ }^{24}$ Research is underway worldwide to develop new capture technologies that could provide reductions in cost and energy penalty as compared to currently available technologies. A positive outcome will very likely be required before any large scale CCS implementation can be envisaged and it must be emphasized again that the IPCC timeline is short.

Geologic storage involves the injection of $\mathrm{CO} 2$ into deep underground formations that, in principle, can permanently and securely contain $\mathrm{CO} 2$. Long-term and short-term risks associated with such storage will need to be carefully quantified and the authorities as well as the public convinced that they are small enough. Even though $\mathrm{CO} 2$ is not a toxic gas, the sudden release of about 1 cubic kilometer, i.e. about 1.8 million tonnes, of $\mathrm{CO} 2$ from Lake Nyos (Cameroon, West Africa) in 1986 killed at least 1,700 people by asphyxiating them. ${ }^{25}$ The quantity of $\mathrm{CO} 2$ released, corresponded to that produced by a large $1 \mathrm{GWe}$ coal power plant in only 3 months. The annual CO2 production from power plants in the US is about 1,300 times higher than what was released at Lake Nyos. Legal and regulatory issues, in particular those associated with long-term liability, are likely to be expected when it will come to choose the sites that will have to permanently host billions of tonnes of $\mathrm{CO} 2$. The World Energy Council cites CCS as one of the key uncertainties ${ }^{26}$ in moving toward a low-carbon economy up to 2050 (together with solar energy and energy storage).

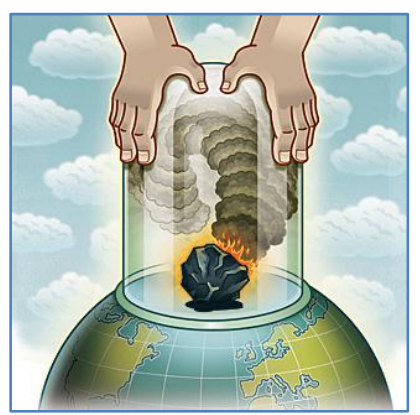

Source: $\underline{\text { www.scientificamerican.com }}$ 


\section{Wind and solar power plants}

Since 2008 the world wind power capacity has more than doubled, ${ }^{27}$ reaching 318 GWe at the end of $2013 .{ }^{28}$ Wind power now provides nearly 4 percent of the world electricity and is expected to grow even more in the near future. With, respectively, $91 \mathrm{GWe}, 61 \mathrm{GWe}, 35$ GWe and 23 GWe of installed capacity (as of the end of 2013), China, the US, Germany and Spain are leading the way. An analysis of utility-scale wind facilities carried out by the US National Renewable Energy Laboratory (NREL) shows that typical power density are comprised between 2 and $10 \mathrm{MWe} / \mathrm{km}^{2}$ with a representative value of about $5 \mathrm{MWe} / \mathrm{km}^{2}$ [29]. Wind capacity factors vary significantly depending on the location and the world average was about 23 percent in 2013. ${ }^{30}$ The US capacity factor was about 33 percent $^{31}$ whereas that in Germany was about 16.5 percent. ${ }^{32}$ Assuming a wind power plant capacity factor of 25 percent, the wind energy density is about 11 million $\mathrm{kWh} /$ year- $\mathrm{km}^{2}$. Even though wind farms cover large areas, most of it remains available for crops or grazing if necessary.
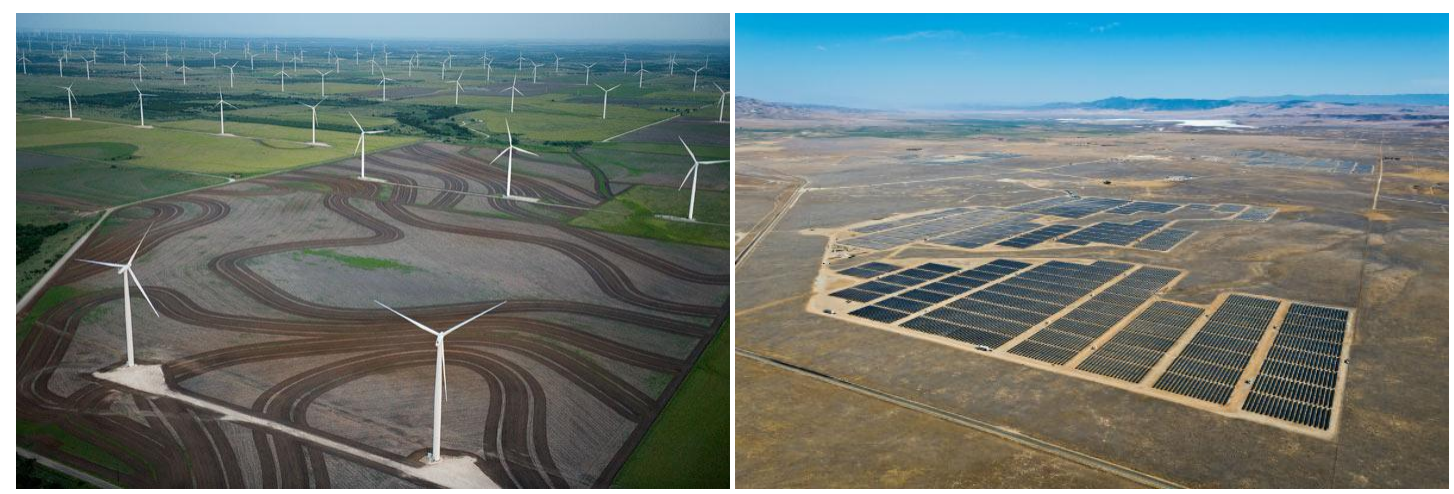

Horse Hollow Wind Farms (0.74 GWe) and California Valley Solar Ranch (0.25 GWe), USA Sources: http://ngm.nationalgeographic.com/ and http://www.power-technology.com/

The world capacity of solar photovoltaic is also increasing very rapidly: 70, 100 and $139 \mathrm{GWe}$ at the end of, respectively, 2011, 2012 and $2013 .^{33} \mathrm{NREL}$ also carried out a land use analysis for a variety of existing US solar power plants. They conclude that, on average, the power density is approximately $30 \mathrm{MWe} / \mathrm{km}^{2}$ [34]. Solar power plant capacity factors are also very dependent on location (e.g. 25 percent for the $\mathrm{US}^{35}$ and 10 percent for Germany ${ }^{36}$ ), and the world average was about $15 \%$ in $2013 .{ }^{37}$ Assuming a solar power plant capacity factor of 15 percent, the average solar energy density is about 39 million $\mathrm{kWh} / \mathrm{year}-\mathrm{km}^{2}$. These numbers are derived from large scale photovoltaic plants located in the Southwest of the US. This region of the US benefits from a more generous solar irradiance than many places in the world (including Europe, India and most of Asia, see figure below) and, consequently, these numbers may provide an upper limit in terms of power and energy density.

For comparison, most of the US nuclear power plants have a power density comprised between 100 and $1300 \mathrm{MWe} / \mathrm{km}^{2}$ with an average of about $500 \mathrm{MWe} / \mathrm{km}^{2}$ [38]. Assuming a typical capacity factor of 80 percent (US nuclear power plants average capacity factor has actually been about 90 percent for the past decade), the average energy density of nuclear power 
plants is about 3.5 billion $\mathrm{kWh} / \mathrm{year}-\mathrm{km}^{2}$, i.e. about 100 times more than solar and 300 times more than wind.

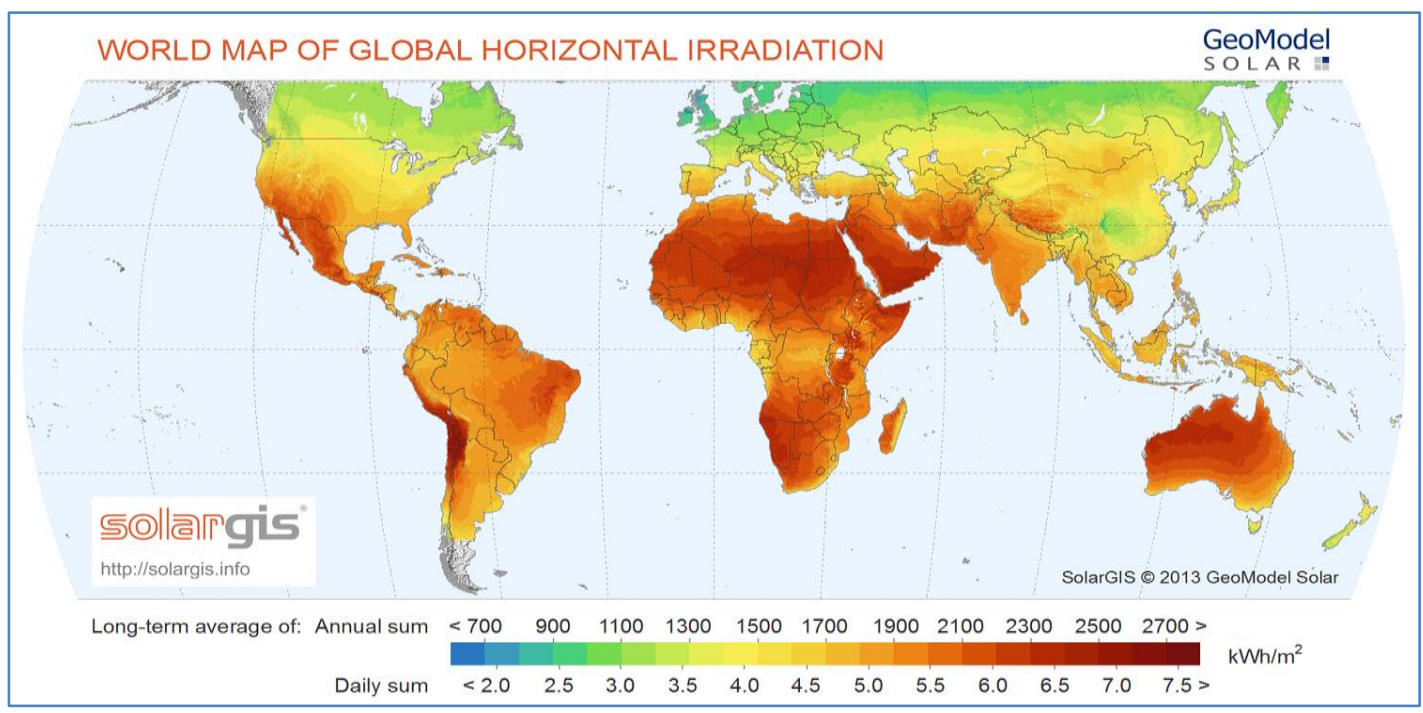

Global solar energy distribution. Source: $\underline{\text { www.solaris.info }}$

A common feature of wind and photovoltaic power plants that may prove valuable in some regions of the world is that they require almost no water to generate electricity because they are not based on a steam cycle. Indeed, thermoelectric power plants such as nuclear, coal or gas power plants necessitate large amount of cooling water. For example, in 2005, thermoelectric cooling water represented 41 percent of water withdrawn and 6 percent of water consumed in the US. ${ }^{39,40}$

Another important characteristic of wind and solar energy is their variability which, for significant penetration, will require the development of cost effective energy storage systems to ensure the necessary constant balance of supply and demand. Although many energy storage systems have already been installed worldwide, pumped hydro systems, with more than $127 \mathrm{GWe}$ installed in $2010,{ }^{41}$ are by far the most widely used. Compressed air energy storage installations are the next largest $(0.44 \mathrm{GWe})$, followed by sodium-sulfur batteries $(0.32 \mathrm{GWe})$.

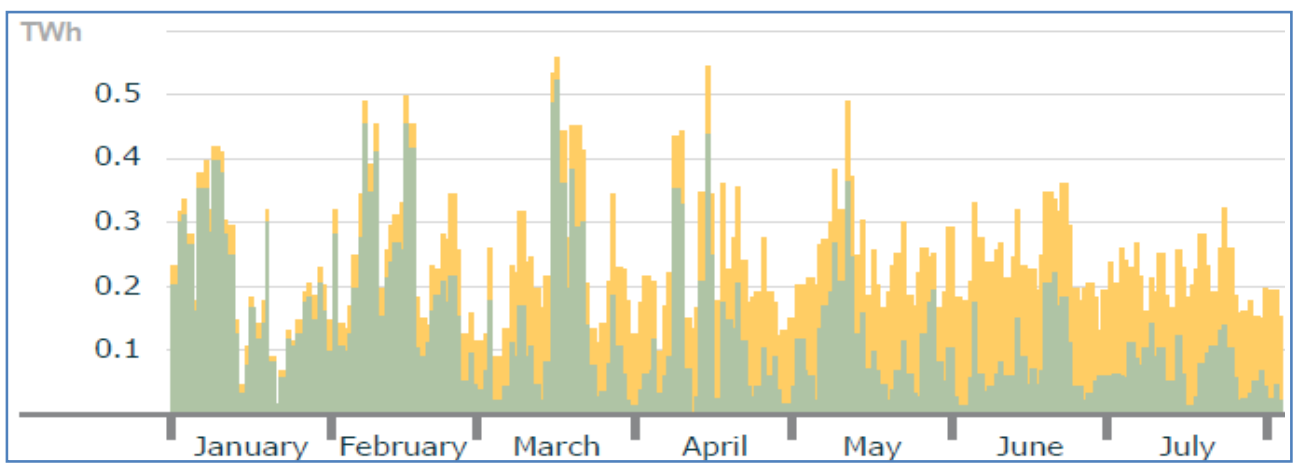

Daily electric production from German wind (green) and solar (yellow) power plants during the first half of 2014. Source: Fraunhofer Institute, "Electricity production from solar and wind in Germany in 2014". 
If wind and solar are to play an important role in reducing greenhouse gas emissions from the power sector (by, let's say, reducing them by a factor of 10 as suggested by the IPCC), large energy storage systems will very likely be necessary. As mentioned earlier, the World Energy Council considers energy storage as one of the key uncertainties in moving toward a low-carbon economy up to 2050 (together with CCS and solar energy). The grid itself could play an important role in mitigating the consequences of the variability of wind and solar and also mitigate, to some extent, the need for energy storage. Indeed, statistically, a grid integrating different variable energy sources (e.g. wind and solar) and covering a very large area should exhibit a smoother behavior than a grid relying on only one energy source, e.g. wind, and covering a smaller area. Or at least this is a claim that is very often made. Looking at the figure above showing the daily electric production from German wind and solar power plants (representing a capacity of about $70 \mathrm{GWe}$ ) during the first half of 2014, the smoothing effect does not appear very effective. The grid may have to cover an entire continent, i.e. Europe or North America for example, for the smoothing effect to actually be effective.

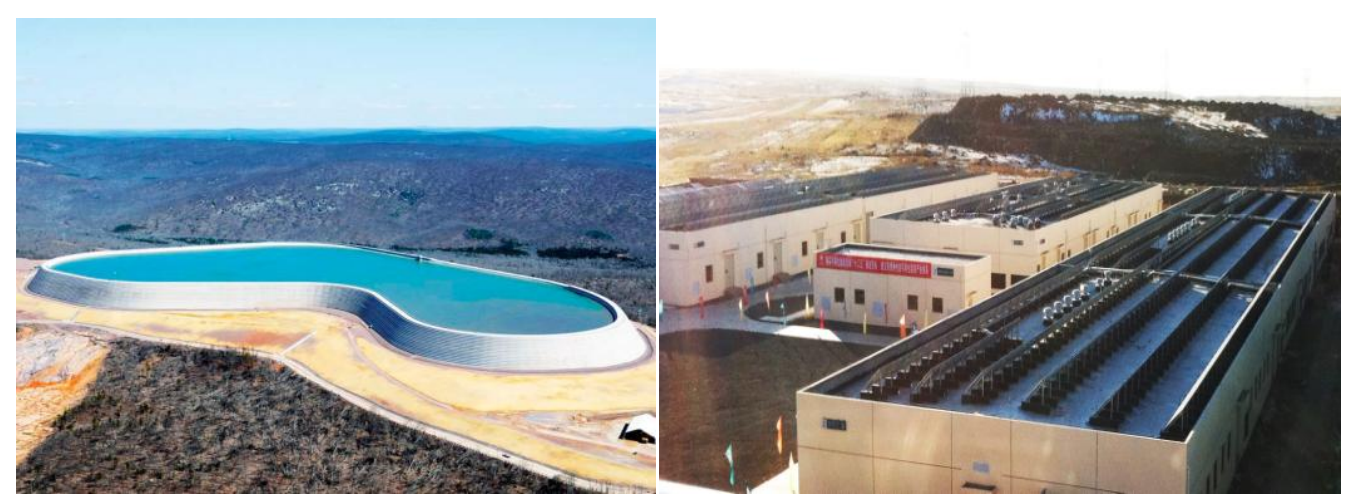

Taum Sauk Pumped Storage Station (0.44 GWe for 8 hours 3.5 GWh), USA; Battery energy storage ( $0.036 \mathrm{GWh})$ located in Zhangbei, China. Source: http://cleantechnica.com/

As an illustration, let's consider a (large) country, or group of (smaller) countries, which need to replace their aging power plants by new low-carbon power plants able to provide a constant power of $500 \mathrm{GWe}$ to the grid (to simplify the discussion variations in demand are not considered). One possibility is to build $500 \mathrm{GWe}$ of wind and/or solar power plants without any energy storage. As mentioned earlier, wind and solar power plants will operate at their nameplate capacity for about 10-30 percent of the time and, consequently, another approximately 450 to $500 \mathrm{GWe}$ of dispatchable power plants (i.e. fossil, nuclear, or renewables such as hydro, geothermal or biomass) would be necessary to maintain grid reliability. These dispatchable power plants have to be able to ramp their power up and down very quickly to ensure a constant balance of demand and supply. In this case wind and solar can only have a limited impact on $\mathrm{CO} 2$ emissions as it will depend mainly on the energy mix used for other 70-90 percent. The actual amount of dispatchable power plants required to maintain an acceptable security of supply would depend on the capacity credits associated to the wind and solar power plants. The capacity credit can be seen as the amount of dispatchable resource that could be replaced by the renewable production, without making the system less reliable. It depends on various parameters such as the capacity factors and the penetration of wind and solar. Capacity 
credits tend to decrease as wind and solar penetration increase ${ }^{42,43}$ and, at very high penetration, a value of no more than 10 percent should be representative, i.e. $1 \mathrm{GWe}$ of wind or solar could replace no more than $0.1 \mathrm{GWe}$ of dispatchable source.

Barnes and Levine from the University of Colorado argue that coal power plants being cycled to compensate for the variability of wind and solar in fact see their fuel consumption per kWh increase $\mathrm{e}^{44}$ and that, consequently, the introduction of wind and solar may lower $\mathrm{CO} 2$ emissions less than expected. The European Union of the Electricity Industry, EURELECTRIC, also observes that the impact of load following on fossil fuel power plant efficiencies and emissions is often overlooked and recommends that stakeholders, and in particular policymakers, engaged in the flexibility debate take this important fact into proper consideration. ${ }^{45}$ For example, their report mentions that a modern combined cycle gas turbine power plant sees its efficiency drop from 55 percent, when it operates at its nameplate capacity, to as low as 35 percent when it operates at 50 percent that value; the consequence is that it burns more fuel and emits more $\mathrm{CO} 2$ per $\mathrm{kWh}$. A careful accounting of these various effects will be required to ensure that the introduction of large quantities of wind and solar power will actually lead to the expected reductions in $\mathrm{CO} 2$ emissions.
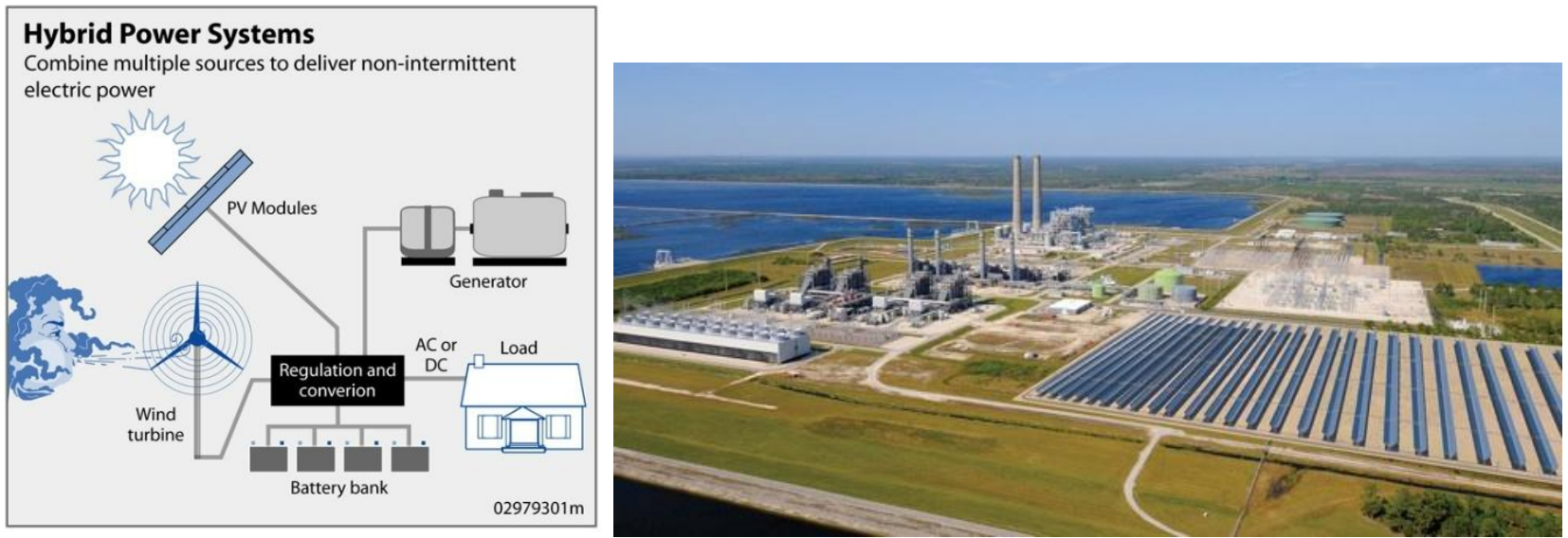

Florida Power \& Light's Martin Next Generation Solar Energy Center is the first hybrid power plant combining natural gas and solar energy (resp. 3.7 GWe and 0.075 GWe) in the United States. Source: www.energy.gov (left) and http://www.cleanenergyactionproject.com/ (right)

Assuming a large fleet of wind and solar power plants with an average capacity factor of 20 percent, an ideal 100 percent wind/solar power sector (for the purpose of this discussion, dispatchable renewables such as hydro, geothermal and biomass are not considered) would require 2,500 GWe of fully interconnected wind and solar power plants distributed over a very large area and would not require any energy storage systems. Indeed, assuming that the area covered by the wind and solar power plants is large enough that their outputs are essentially uncorrelated, it is then statistically possible that $500 \mathrm{GWe}$ be available all the time. As mentioned above, the grid interconnection would probably have to be at the continent level, i.e. Europe of North America for example. These numbers are derived by assuming that the transmission losses over such a large grid are small and that the availability factor of the wind and solar power plants is $100 \%$, i.e. that the power plants are always available when the wind and sun are 
available. Taking these two parameters into account would probably require adding of the order of 10 to $20 \%$ to the generating capacity.

The probability of encountering such an ideal situation is small and a 100 percent wind/solar power sector may actually require even more GWe of wind and solar as well as hundreds of GWe of storage capacities in order to ensure the overall reliability of the system. As an example, a system using 3,000 GWe of wind/solar coupled with $500 \mathrm{GWe}$ of storage capacity would probably meet all requirements regarding grid reliability. During 20 percent of the time, wind and solar plants would supply $500 \mathrm{GWe}$ directly to the grid while 2,500 GWe would be used to charge storage systems. The energy stored by these $2,500 \mathrm{GWe}$ operating 20 percent of the time would, in principle, be sufficient to provide $500 \mathrm{GWe}$ to the grid for the other 80 percent of the time (assuming a typical 80 percent round trip efficiency of the storage systems ${ }^{46}$ ). As above, transmission losses are ignored and the availability factor of the wind and solar power plants is assumed to be $100 \%$. This discussion is highly simplified on purpose and more details about the impact of wind and solar on the grid can be found in [47] and [48].

This option would dramatically cut greenhouse gas emissions from the power sector and its viability rests on the use of a large energy storage system. The actual number of GWe of storage depends on many parameters such as (1) how many GWh are necessary, (2) how many GWh can be stored per GWe of storage, (3) the availability factors of the storage systems and (4), most importantly, the level of grid reliability required by the decision makers. As for carbon capture and storage, a range of energy storage technologies exist in various stages of development and the major challenge is to extrapolate them so they have a meaningful impact on $\mathrm{CO} 2$ emissions in the next 40-50 years. Note that the same reduction of greenhouse gas emissions could be obtained with a $625 \mathrm{GWe}$ fleet of nuclear power plants (assuming a typical capacity factor of 80 percent).

Assuming the energy density of wind and solar power plants presented above, the figures below illustrate, on two US maps, the land use of 1,200 GWe of on-shore wind farms as well as that of 2,000 GWe of solar farms necessary for each system to provide a constant power of $250 \mathrm{GWe}$ to the grid when coupled to storage systems such as pumped hydro or compressed air energy storage. The large areas that are required would be challenging but not unrealistic for large countries such as the US as long as solutions for energy storage are available. On the other hand, land use could be more problematic for smaller countries such as in Europe for example. 

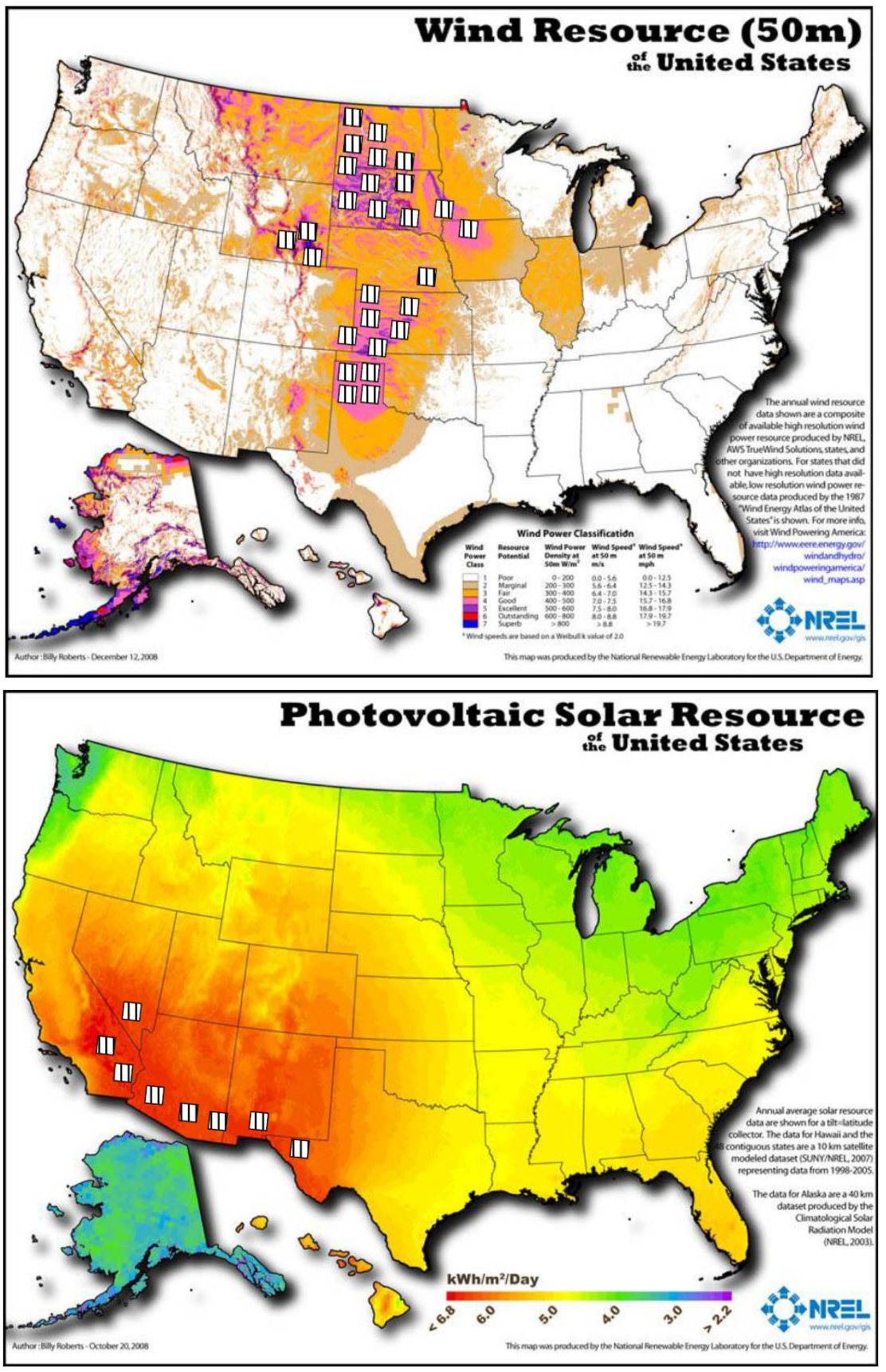

Illustration of the land use of 1,200 GWe of on-shore wind farms $\left(240,000 \mathrm{~km}^{2}\right)$ and 2,000 GWe of solar PV $\left(70,000 \mathrm{~km}^{2}\right)$ necessary for each to provide a constant power of $250 \mathrm{GWe}$ to the grid when coupled to storage systems such as pumped hydro or compressed air energy storage. Average wind and PV farms capacity factor $=25 \%$ and $15 \%$, Energy storage round trip efficiency $=80 \%$. Each square is about 9,000 $\mathrm{km}^{2}$, i.e. the size of Yellowstone National Park. Note: The author, not NREL, scaled and positioned the squares representing the areas covered by the wind and solar farms 


\section{Nuclear power plants}

To produce 7 billion $\mathrm{kWh}$ per year, a typical $1 \mathrm{GWe}$ nuclear reactor of current pressurized water technology ${ }^{49}$ uses 17.5 tonnes of low enriched uranium per year, corresponding to 35 fresh fuel assemblies. To produce these 17.5 tonnes of low enriched uranium, it is necessary to process about 150 tonnes of natural uranium. In the mean time, 35 used fuel assemblies containing also 17.5 tonnes made up mainly of uranium ( $\sim 94$ percent) but also about $1,100 \mathrm{~kg}$ of other, highly radioactive, elements (out of which $200 \mathrm{~kg}$ is plutonium) need to be stored each year, i.e. 0.0025 gram per $\mathrm{kWh}$. About 130 tonnes of depleted uranium coming from the enrichment process also need to be stored safely to keep it from interacting with the environment. Like natural uranium, depleted uranium displays only a very low level of radioactivity but, as a heavy metal, it will produce similar health effects as lead and cadmium if ingested. ${ }^{50}$ No greenhouse gases or other air pollutants are produced during operation.

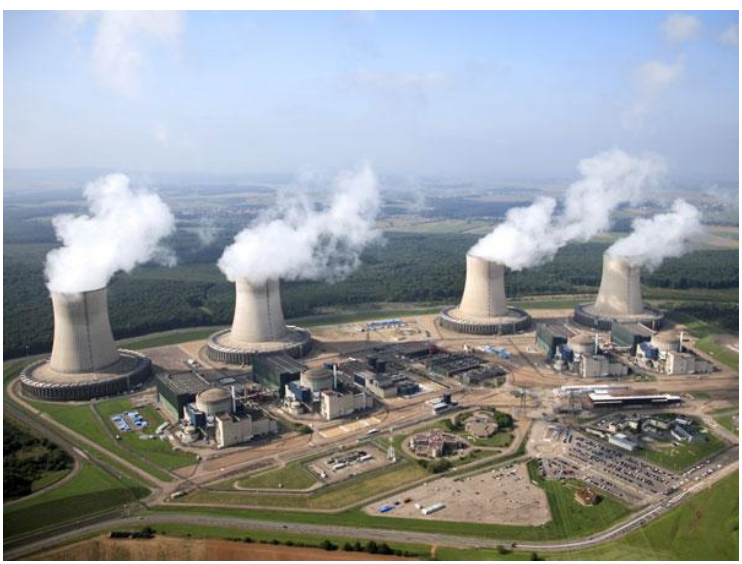

Cattenom nuclear power plant (5.2 GWe), France Source: http://energie.edf.com/

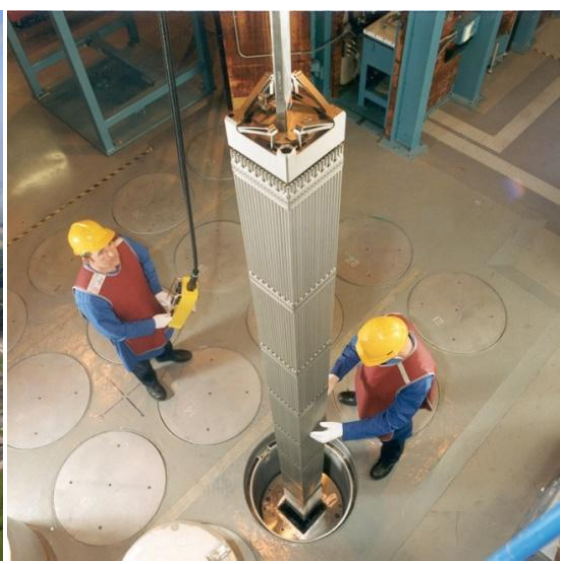

Nuclear fuel assembly

Source: www.pntl.co.uk/

The dimensions (in meter) of a typical fuel assembly are $0.21 \times 0.21 \times 4$ so that the volume occupied by these 35 fuel assemblies is about 6.2 cubic meters, i.e. about $0.0009 \mathrm{cu}-$ bic centimeter per kWh (about the size of a grain of sand). Assuming an average consumption of $8,000 \mathrm{kWh}$ per year, a person living in an industrialized country would be responsible for the production of about 7.2 cubic centimeters of used nuclear fuel per year weighing 20 grams if the electricity came only from nuclear power plants. It would take about 50 years for this person to fill the equivalent of a can of soda (355 cubic centimeters) with used nuclear fuel.

The management of these 35, highly radioactive, used fuel assemblies generated every year by a $1 \mathrm{GWe}$ reactor varies from country to country. In the US, for example, they are safely stored next to the reactor, either in pools or dry casks, ${ }^{51}$ waiting for their final destination, which could be either a deep geological disposal facility or a reprocessing plant where they would be dismantled in order to separate their different constituents (uranium, plutonium, fission products, etc.) for potential further use in breeder reactors for example (see below). Most of the controversy about nuclear power concentrates on what to do with 
these 35 used fuel assemblies generated per reactor each year. Technical solutions exist and the management of used nuclear fuel assemblies is at least as much a political and societal problem as an actual technical problem.

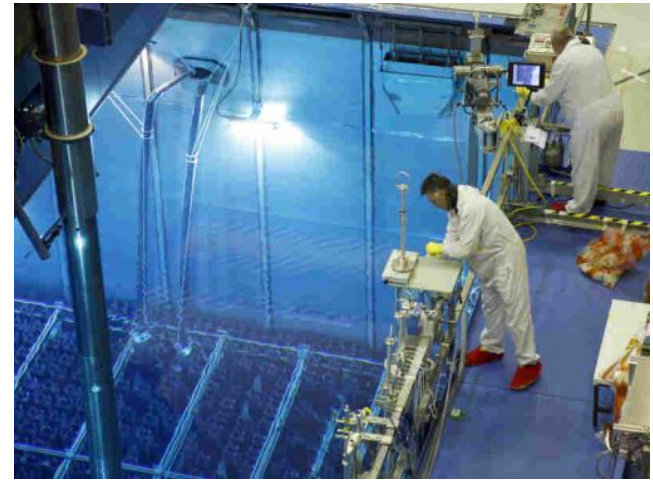

Used fuel pool

Source: $\underline{\text { http://www.npr.org/ }}$

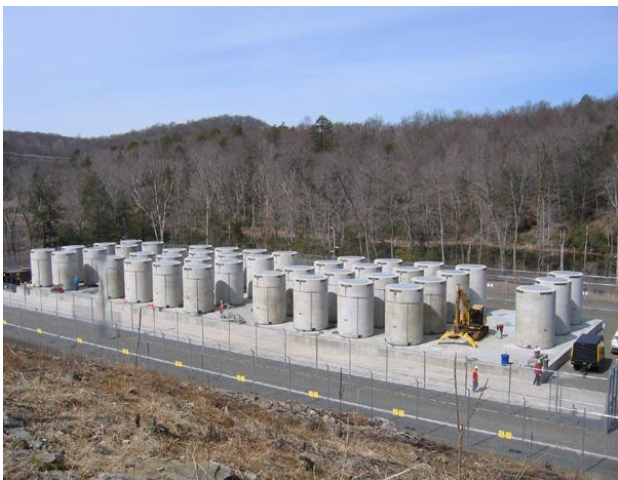

Used fuel dry cask storage

Source: http://www.connyankee.com/

With approximately 70,000 tonnes of accumulated commercial used fuel assemblies, ${ }^{52}$ the US has the largest inventory in the world. If the 700 tonnes of plutonium contained in these 70,000 tonnes of used fuel were used in nuclear reactors of current technolo$\mathrm{gy}^{53}$ they could generate about 3 trillion $\mathrm{kWh}$, i.e. equivalent to 1.5 billion tonnes of coal. However, from an energy standpoint, the best use of this plutonium would be in fast breeder reactors (see below) where it could be used to produce electricity for thousands of years. These 700 tonnes of plutonium would be sufficient to start about 50 fast breeder reactors capable of delivering $50 \mathrm{GWe}$ to the grid. The US commercial used fuel assemblies inventory is currently increasing annually by about 2,000 tonnes which correspond about 4,000 used nuclear fuel assemblies and a volume of about 705 cubic meters, i.e. the equivalent of about 6.5 standard 53-foot semi-trailers. Plutonium coming from nuclear weapons could also be used in nuclear reactors of current technology to produce electricity. One kilogram of such plutonium could generate about 10 million $\mathrm{kWh}$ while decreasing the risk of proliferation.

A recent report from the Nuclear Energy Agency ${ }^{54}$ compares both radioactive and hazardous wastes (potentially dangerous non-radioactive wastes such as arsenic and mercury for example). The report highlights that the safe disposal of radioactive waste is not the uniquely difficult issue that is perceived by the media, much of the public and by many politicians. Because radioactivity decays over time the hazard associated with radioactive waste also decreases with time. On the other hand, since hazardous wastes do not decay over time, their hazards remain in principle indefinitely. In this regard, both categories share the issues associated with long-lived wastes, i.e. longevity is not unique to radioactive wastes. Finally, even though the quantities of hazardous wastes are much larger than those of radioactive wastes, the report points out that their disposal has not attracted the same degree of public and political attention.

If the totality of the present world electricity production from coal, gas, oil and nuclear combined (17.6 trillion $\mathrm{kWh}$ ) came from current technology nuclear power plants alone, the currently estimated 8 to 24 million tonnes ${ }^{55}$ of uranium resources (not including 
seawater) would last between 20 and 60 years. Compared to the current situation, this would represent an increase of the production of electricity from nuclear by a factor 6.8 , i.e. about 2,500 GWe instead of the current $370 \mathrm{GWe}$. Worthwhile noting is that, unlike coal and gas, uranium has essentially no other use than power production. Seawater has long been regarded as a possible source of uranium due to the large amount of contained uranium (over 4 billion tonnes), however, because of the low concentration of uranium in seawater (3-4 parts per billion), developing a cost-effective method of extraction is difficult. Based on these numbers, it is concluded that current technology nuclear power plants could not sustain such a capacity increase for very long unless the actual uranium resources are in fact larger than current estimates and/or a cost-effective method of extracting uranium from seawater was available. If that was the case, current technology nuclear power plants could generate the equivalent of today electricity generated from coal, gas, oil and nuclear combined for about 10,000 years.

To alleviate the need for natural uranium, several countries throughout the world (especially Russia, France, Japan, India, China and the US) have been actively pursuing the development of a different, more efficient, kind of nuclear reactor for decades: the sodiumcooled fast breeder reactor. Six commercial size prototypes with electrical output ranging from 0.25 to $1.2 \mathrm{GWe}$ have already been constructed and operated. ${ }^{56}$ In total, nearly 350 reactor-years of operation have been acquired for sodium-cooled fast reactors. With a power of $0.8 \mathrm{GWe}$, the Russian BN-800 reactor is the latest in this family of sodium-cooled fast reactors. It achieved first criticality in 2014 and should begin commercial operation in 2015. India's Department of Atomic Energy has also announced that their 0.5 GWe Prototype Fast Breeder Reactor (PFBR) will be ready for operation in 2015.

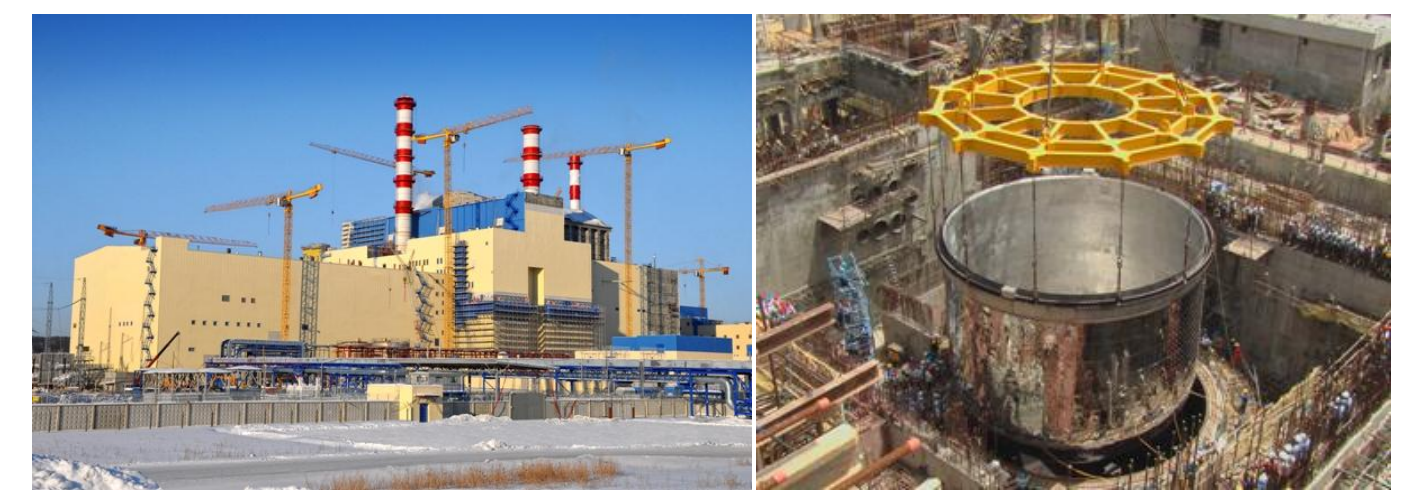

BN-800 nuclear power plant (0.8 GWe), Russia - Prototype Fast Breeder Reactor (0.5 GWe), India Source: http://www.okbm.nnov.ru and http://www-pub.iaea.org/

A $1 \mathrm{GWe}$ fast breeder reactor would recycle most of its fuel and would require only between 1 and 1.5 tonne of natural uranium per year instead of 150 tonnes for current reactors. It would also require between 10 and 15 tonnes of spent fuel to be reprocessed each year out of which only about 1 tonne of radioactive fission product high level waste would need to be disposed of whereas the rest (uranium and plutonium) could be reutilized. This high level waste would remain radioactive for a much shorter period of time (a few centuries) than in the case of the direct disposal of used nuclear fuel, which would make it probably more ac- 
ceptable to the public. In addition to about 5 to 7 tonnes of plutonium present in the reactor core, a similar amount of plutonium would be located outside the core in fuel cycle facilities such as cooling ponds, fuel reprocessing facilities and fuel fabrication facilities. With this regard, it is very important to note that a fast reactor fuel cycle can be designed such that there is never, at any location, a uranium-plutonium mixture that would be more attractive than current fuels using low enriched uranium material. Spent fuel reprocessing is already an industrial reality in some countries and, for example, with its current capacity of 1,700 tonnes per year the French reprocessing plant at La Hague ${ }^{57}$ would be sufficient to reprocess the fuel coming from between 110 and 170 large $1 \mathrm{GWe}$ fast breeder reactors.

With world natural uranium resource amounting to at least 8 million tonnes and another 1.5 to 2 million tonnes of depleted uranium accumulated from the operation of uranium enrichment plants throughout the world, fast breeder reactors could provide electricity safely and reliably for at least 3,000 years even if, alone, it had to produce the total current electrical power coming from coal, gas, oil and nuclear combined. Furthermore, in addition to uranium, fast breeder reactors could also use thorium as a fuel which would at least double the amount of energy these reactors could produce. Until fusion power becomes a viable alternative, uranium (and potentially thorium) used in fast breeder reactors represent the largest source of concentrated energy available to mankind.

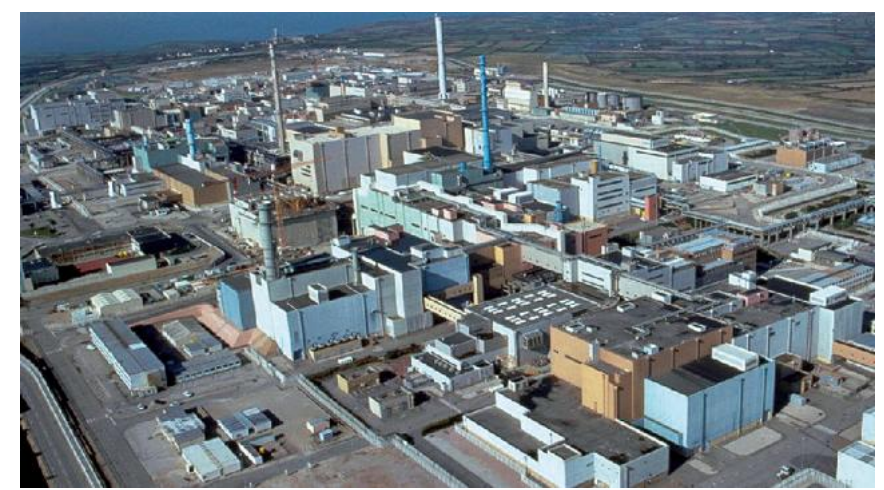

Fuel reprocessing plant of La Hague, France

Source: http://nuclearmanagementpartners.com/

Other technologies, such as molten salt reactors or gas-cooled reactors, ${ }^{58}$ aiming at the same goal, i.e. the full utilization of uranium and/or thorium, are also being studied. These technologies may have some potential but are in a much less advanced stage than that of the sodium-cooled fast reactor. Also worthwhile mentioning is the concept currently being developed by the nuclear engineering company TerraPower, created by the billionaire and philanthropist Bill Gates in 2006. In principle the concept ${ }^{59}$ is similar to that of sodiumcooled fast breeder reactors with the important difference that it would not require reprocessing the fuel, i.e. the used fuel would have to be disposed of in a geological repository. Because the fuel is not reprocessed, the concept is not as efficient at using uranium as a breeder reactor reprocessing its fuel; it would require a few tonnes of natural uranium per year for a $1 \mathrm{GWe}$ reactor versus only 1 to 1.5 tonnes for a breeder reactor reprocessing its 
fuel. Compared to currently operating reactors it would however use much less natural uranium and much less used fuel would also need to be disposed of.

Approximately 2,500 large $1 \mathrm{GWe}$ fast reactors would be necessary to produce the same amount of electricity as the current coal, gas, oil and nuclear power plants combined (17.6 trillion $\mathrm{kWh}$ ). Since between approximately 1970 and 1990, the US alone was able to bring on-line an average of about $5 \mathrm{GWe}$ per year, it appears reasonable to think that nowadays, worldwide, at least $50 \mathrm{GWe}$ could be brought on-line every year if deemed necessary. At that rate, it would take 50 years to build a fast reactor fleet of 2,500 GWe. Needless to say that this would be very challenging for the nuclear industry and a lot will depend on what will happen in China and India, two countries aggressively pursuing nuclear power development. China's State Council published the Energy Development Strategy Action Plan, 20142020 on November 19, 2014. Fast breeder reactors are seen as the main technology for China's long-term use of nuclear energy; Deployment of current technology pressurized water reactors is expected to stabilize at $200 \mathrm{GWe}$ by around 2040 , whereas the share of fast reactors is expected to increase from 2020 to at least $200 \mathrm{GWe}$ by 2050 and $1400 \mathrm{GWe}$ by $2100 .^{60}$ The Indian Atomic Energy Commission is also planning to deploy a nuclear fleet of about 500 to $600 \mathrm{GWe}$ over the next 50 years. ${ }^{61}$

As mentioned in the introduction, even though very relevant to a discussion on the power sector, the current difficulties experienced by the nuclear industry, caused in part by the very low price of natural gas, in some regions of the world are not analyzed. The reason is that the author chose to focus on the potential of each energy source and present facts and figures to make, hopefully, relevant comparisons. The potential of a technology is independent of short-term economic considerations; for example who is to say that natural gas will still be cheap ten years from now? Furthermore, the delays and cost overruns experienced in recent nuclear constructions are more a sign that both the supply chain and the project management needs to be greatly improved than a sign of a fundamental flaw in the technology.

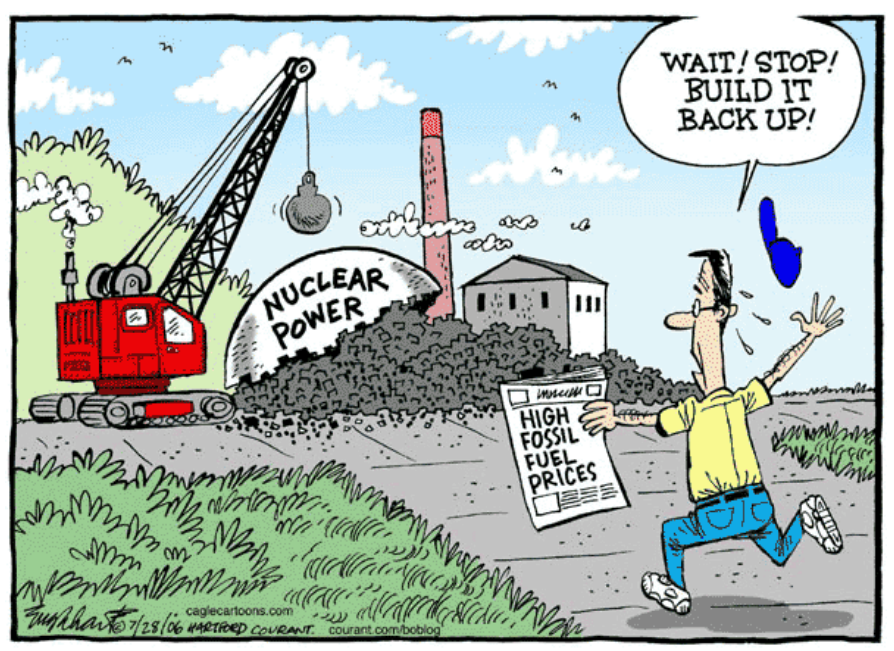

Source: www.caglecartoons.com 


\section{Cost considerations}

Even though the cost of a $1 \mathrm{GWe}$ nuclear power plant may be higher than that of a 1 GWe wind or solar power plant, the investment necessary to implement a 100 percent wind/solar option as discussed in section 3 would very likely be higher than that necessary to implement a 100 percent nuclear option because of the much larger number of GWe required. For example, the U.S. Energy Information Administration recently (2013) estimated the overnight capital cost of a nuclear power plant at $\$ 5,530 / \mathrm{kW}$, that of onshore and offshore wind at, respectively, $\$ 2,213 / \mathrm{kW}$ and $\$ 6,230 / \mathrm{kW}$, and that of photovoltaic at $\$ 3,873 / \mathrm{kW} .^{62}$ NREL provides consistent estimates for wind: between $\$ 1,400 / \mathrm{kW}$ and $\$ 2,900 / \mathrm{kW}$ for utility-scale onshore wind projects and between $\$ 2,500 / \mathrm{kW}$ to $\$ 6,500 / \mathrm{kW}$ for utility-scale offshore wind projects with a U.S. reference cost estimate of $\$ 5,600 / \mathrm{kW}$. ${ }^{63}$ Regarding energy storage the U.S. Energy Information Administration reports an overnight capital cost of $\$ 5,288 / \mathrm{kW}$ for pumped hydro ${ }^{62}$ whereas Ref. [46] gives a range of $\$ 5,500 / \mathrm{kW}$ to $\$ 8,000 / \mathrm{kW}$. The same reference gives a range of $\$ 4,500 / \mathrm{kW}$ to $\$ 4,900 / \mathrm{kW}$ for compressed air energy storage installations. Considering energy storage systems as part of the overall renewable energy systems is important as it allows internalizing the cost of variability.

Let's consider again the same country as in section 3 which needs a new low-carbon power sector able to supply a constant power of $500 \mathrm{GWe}$ to the grid. Assuming a value of $\$ 2,500 / \mathrm{kW}$ for either wind or solar and $\$ 4,500 / \mathrm{kW}$ for energy storage, the ideal 100 percent wind/solar case requiring no energy storage would cost about $\$ 6.25$ trillion $(2,500 \mathrm{GWe} \times$ $\$ 2.5$ billion/GWe); the 100 percent wind/solar case with $500 \mathrm{GWe}$ of energy storage would cost about $\$ 9.75$ trillion $(3,000 \mathrm{GWe} \times \$ 2.5$ billion $/ \mathrm{GWe}+500 \mathrm{GWe} \times \$ 4.5$ billion $/ \mathrm{GWe})$ and the 100 percent nuclear case would cost about $\$ 3.5$ trillion $(625 \mathrm{GWe} \times \$ 5.53$ billion/GWe). A $625 \mathrm{GWe}$ reactor fleet of current technology would generate about 10,900 tonnes of used fuel every year ( $625 \mathrm{GWe} \times 17.5$ tonnes/GWe-year) that would need to be either reprocessed or disposed of. The additional capital cost related to these facilities would be relatively small in comparison to the capital cost of nuclear power plants. Another important cost parameter is the lifespan of the investment. Whereas nuclear power plants can operate for at least 40 years and probably up to 60 years, there are currently more uncertainties regarding the lifespan of solar panels, wind turbines and energy storage systems (other than pumped hydro).

Regarding coal-fired and gas-fired power plants with CCS, the U.S. Energy Information Administration reports an overnight capital cost comprised between $\$ 4,724 / \mathrm{kW}$ and $\$ 6,599 / \mathrm{kW}$ for coal (depending on the technology, i.e. advanced pulverized coal or integrated gasification combined cycle) and of $\$ 2,095 / \mathrm{kW}$ for gas. Assuming a typical capacity factor of 80 percent and also that 25 percent of the power is necessary for carbon capture systems (see section 2), 835 GWe of coal or gas-fired power plants with CCS are necessary to provide a constant power of $500 \mathrm{GWe}$ to the grid. The capital cost necessary for a 100 percent coal + CCS would be between $\$ 3.9$ and $\$ 5.5$ trillion whereas that for the 100 percent gas + CCS would be about $\$ 1.7$ trillion. Respectively about 4 to 6 billion tonnes and 2.5 billion tonnes of $\mathrm{CO} 2$ need to be captured, compressed, transported and finally stored underground 
every year for coal and gas-fired power plants. In the case of coal, approximately 200 to 300 million tonnes of ash would also need to be managed every year.

\begin{tabular}{|c|c|c|c|c|c|}
\hline & \multicolumn{2}{|c|}{ Plant Characteristics } & \multicolumn{3}{|c|}{ Plant Costs (2012\$) } \\
\hline & $\begin{array}{r}\text { Nominal } \\
\text { Capacity } \\
\text { (MW) }\end{array}$ & $\begin{array}{l}\text { Heat Rate } \\
\text { (Btu/kWh) }\end{array}$ & $\begin{array}{r}\text { Overnight } \\
\text { Capital Cost } \\
(\$ / \mathrm{kW})\end{array}$ & $\begin{array}{r}\text { Fixed O\&M } \\
\text { Cost }(\$ / k W-y r)\end{array}$ & $\begin{array}{r}\text { Variable } \\
\text { O\&M Cost } \\
\text { (\$/MWh) }\end{array}$ \\
\hline \multicolumn{6}{|l|}{ Coal } \\
\hline Single Unit Advanced PC & 650 & 8,800 & $\$ 3,246$ & $\$ 37.80$ & $\$ 4.47$ \\
\hline Dual Unit Advanced PC & 1,300 & 8,800 & $\$ 2,934$ & $\$ 31.18$ & $\$ 4.47$ \\
\hline Single Unit Advanced PC with CCS & 650 & 12,000 & $\$ 5,227$ & $\$ 80.53$ & $\$ 9.51$ \\
\hline Dual Unit Advanced PC with CCS & 1,300 & 12,000 & $\$ 4,724$ & $\$ 66.43$ & $\$ 9.51$ \\
\hline Single Unit IGCC & 600 & 8,700 & $\$ 4,400$ & $\$ 62.25$ & $\$ 7.22$ \\
\hline Dual Unit IGCC & 1,200 & 8,700 & $\$ 3,784$ & $\$ 51.39$ & $\$ 7.22$ \\
\hline Single Unit IGCC with CCS & 520 & 10,700 & $\$ 6,599$ & $\$ 72.83$ & $\$ 8.45$ \\
\hline \multicolumn{6}{|l|}{ Natural Gas } \\
\hline Conventional CC & 620 & 7,050 & $\$ 917$ & $\$ 13.17$ & $\$ 3.60$ \\
\hline Advanced CC & 400 & 6,430 & $\$ 1,023$ & $\$ 15.37$ & $\$ 3.27$ \\
\hline Advanced $C C$ with $C C S$ & 340 & 7,525 & $\$ 2,095$ & $\$ 31.79$ & $\$ 6.78$ \\
\hline Conventional CT & 85 & 10,850 & $\$ 973$ & $\$ 7.34$ & $\$ 15.45$ \\
\hline Advanced CT & 210 & 9,750 & $\$ 676$ & $\$ 7.04$ & $\$ 10.37$ \\
\hline Fuel Cells & 10 & 9,500 & $\$ 7,108$ & $\$ 0.00$ & $\$ 43.00$ \\
\hline \multicolumn{6}{|l|}{ Uranium } \\
\hline Dual Unit Nuclear & 2,234 & N/A & $\$ 5,530$ & $\$ 93.28$ & $\$ 2.14$ \\
\hline \multicolumn{6}{|l|}{ Biomass } \\
\hline Biomass CC & 20 & 12,350 & $\$ 8,180$ & $\$ 356.07$ & $\$ 17.49$ \\
\hline Biomass BFB & 50 & 13,500 & $\$ 4,114$ & $\$ 105.63$ & $\$ 5.26$ \\
\hline \multicolumn{6}{|l|}{ Wind } \\
\hline Onshore Wind & 100 & N/A & $\$ 2,213$ & $\$ 39.55$ & $\$ 0.00$ \\
\hline Offshore Wind & 400 & N/A & $\$ 6,230$ & $\$ 74.00$ & $\$ 0.00$ \\
\hline \multicolumn{6}{|l|}{ Solar } \\
\hline Solar Thermal & 100 & N/A & $\$ 5,067$ & $\$ 67.26$ & $\$ 0.00$ \\
\hline Photovoltaic & 20 & N/A & $\$ 4,183$ & $\$ 27.75$ & $\$ 0.00$ \\
\hline Photovoltaic & 150 & N/A & $\$ 3,873$ & $\$ 24.69$ & $\$ 0.00$ \\
\hline \multicolumn{6}{|l|}{ Geothermal } \\
\hline Geothermal - Dual Flash & 50 & N/A & $\$ 6,243$ & $\$ 132.00$ & $\$ 0.00$ \\
\hline Geothermal - Binary & 50 & N/A & $\$ 4,362$ & $\$ 100.00$ & $\$ 0.00$ \\
\hline \multicolumn{6}{|l|}{ Municipal Solid Waste } \\
\hline Municipal Solid Waste & 50 & 18,000 & $\$ 8,312$ & $\$ 392.82$ & $\$ 8.75$ \\
\hline \multicolumn{6}{|l|}{ Hydroelectric } \\
\hline Conventional Hydroelectric & 500 & N/A & $\$ 2,936$ & $\$ 14.13$ & $\$ 0.00$ \\
\hline Pumped Storage & 250 & N/A & $\$ 5,288$ & $\$ 18.00$ & $\$ 0.00$ \\
\hline
\end{tabular}

Estimates of power plant capital and operating costs.

Source: U.S. Energy Information Administration, "Updated Capital Cost Estimates for Utility Scale Electricity Generating Plants", 2013 


\section{Risk considerations}

The perceived risk associated with the use of nuclear power is in general higher than the actual risk. A nuclear reactor accident can potentially have severe consequences, such as the displacement of large populations, but it must be emphasized that the three worst nuclear accidents so far (Three Mile Island, Chernobyl and Fukushima) have not caused any "Armageddon" or "China Syndrome" predicted by some media and groups opposed to the use of nuclear power.

The 2008 report issued by the United Nations Scientific Committee on the Effects of Atomic Radiation regarding the health effects due to radiations from the Chernobyl accident ${ }^{64}$ concludes that out of the 134 plant staff and emergency workers who were exposed to high doses of radiation, 28 died whereas the major impact on the survivors was skin injuries and radiation-induced cataracts. Regarding the several hundred thousand people involved in recovery operations, the committee concludes that, apart from indications of an increase in the occurrence of leukemia and cataracts among those who received higher doses, there is no evidence of health effects that can be attributed to radiation exposure. Out of the 6,000 thyroid cancers observed to date only 15 cases have proved fatal (as of 2005). Finally it concludes that "the vast majority of the population need not live in fear or serious health consequences from the Chernobyl accident."

Regarding Fukushima, the 2013 report issued by the United Nations Scientific Committee on the Effects of Atomic Radiation ${ }^{65}$ states that no radiation-related deaths or acute diseases have been observed among the workers and general public exposed to radiation from the accident and that the doses to the general public are generally low or very low. No discernible health effects are expected among exposed members of the public or their descendants. On the other hand, the earthquake and subsequent tsunami which claimed more than 20,000 lives will certainly have a long lasting psychological impact on the population. The conclusions reached by this authoritative committee after years of studies (for Chernobyl, less so for Fukushima) sharply contrasts with the sometimes confusing and alarmist information relayed in the media.

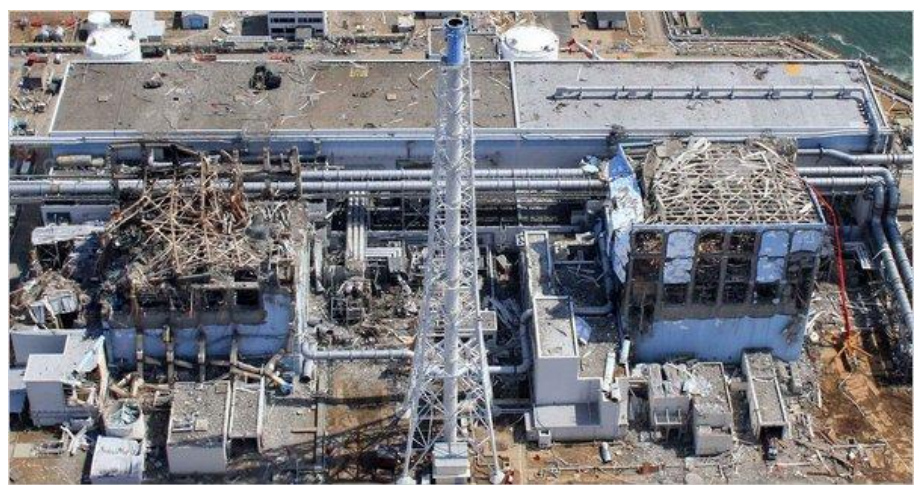

The Fukushima Daiichi nuclear plant damaged by a tsunami on March 11, 2011

Source: $\underline{\text { http://www.nytimes.com/ }}$ 
Severe nuclear accidents expose only very few people to high radiation doses (134 for Chernobyl, none for TMI and Fukushima) but can on the other hand expose large populations to low radiation doses that are of the same order as that coming from the natural background radiations or a several times higher than that. Natural background radiations expose people to between 1 and 10 milli-sieverts per year (the sievert is a unit that characterizes the biological effects of radiations, i.e. the health effects, see the figure at the end for more details) with a world average of about 2.5 milli-sieverts per year. Radiation exposures of up to 100 milli-sieverts per year are still considered low. Current regulations in place to protect the public are based on the precautionary principle and limit the potential dose increase caused by a radiological accident to 1 milli-sievert per year, i.e. a fraction of the natural dose. To put this number in perspective, a person moving from Australia to Finland would see his or her annual dose from natural sources increase by about 6 milli-sieverts. As another reference point, a CT scan exposes the patient to between 10 and 20 milli-sieverts. In order to understand the consequences of severe nuclear accidents on the health of the exposed populations it is fundamental to understand how the effects of low radiation doses on people are estimated. The following paragraphs are an attempt to tackle this issue.

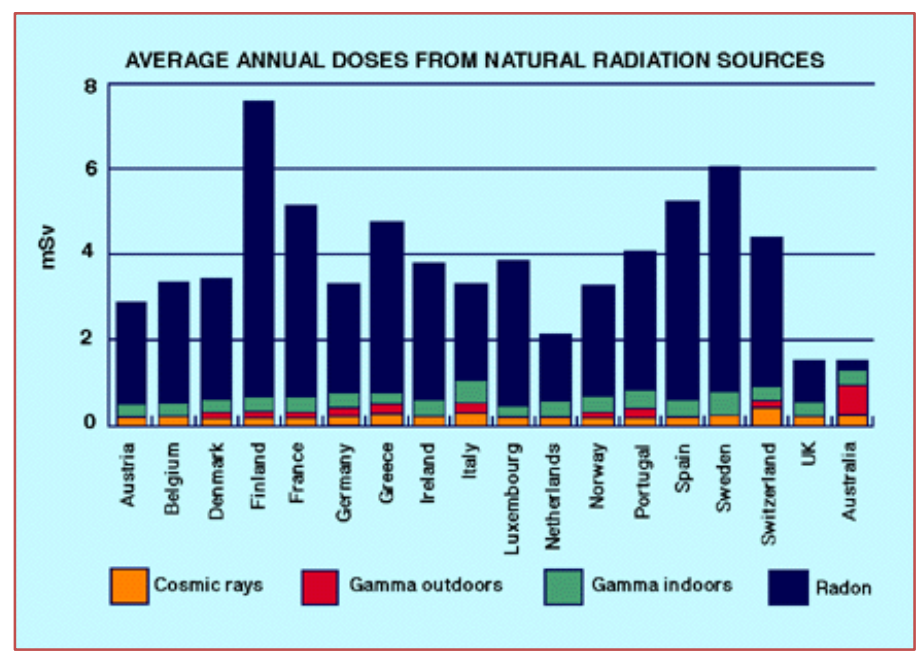

Source: $\quad$ http://www.world-nuclear.org/info/Safety-and-Security/Radiation-andHealth/Nuclear-Radiation-and-Health-Effects/

The effects of low radiation doses on people are estimated using a model called linear no-threshold model or LNT ${ }^{66}$ This model extrapolates what we know for sure about the health effects of high radiation doses ${ }^{67}$ to low radiation doses; If a group of people is exposed to a high dose of radiation, the effects are clearly measurable and quantifiable and the higher the dose the worse the effects are. This is not the case for low radiation doses for which no direct effects are observed. So this LNT model simply states that since for a given high dose of radiation corresponds a certain quantifiable effect (e.g. probability of developing a cancer) then for a lower dose, let's say 1,000 times lower, the effects will also be 1,000 lower than for the high dose. When this very low probability of developing a cancer is applied to a large population, the result is that thousands of potential cancers are obtained though there is actually no evidence of risk at low radiation doses. If this approach was applied to common sub- 
stances such as coffee, it would be concluded that millions of people die every day. Indeed, assuming that 1 billion people have a cup of coffee every day and that a cup contains 0.5 to 1 percent of the lethal dose of caffeine, the LNT model would lead to the conclusion that the consumption of coffee is fatal to 5 to 10 million people every day. This, of course, is not the case because a threshold is assumed below which caffeine has no impact on health.

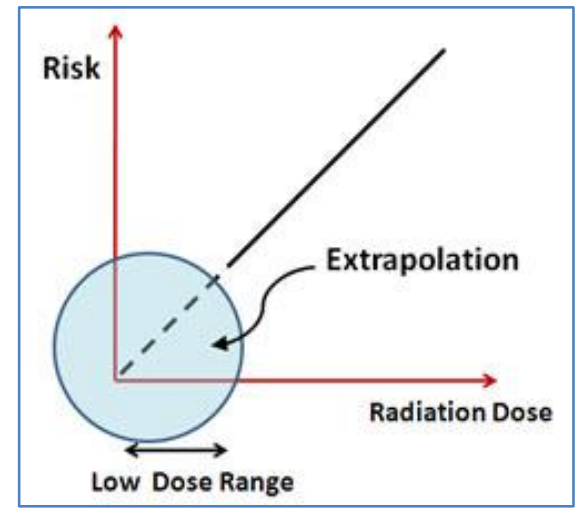

Illustration of the linear no-threshold model or LNT

The LNT model has always been controversial and, for example, the French Academies report ${ }^{68}$ concluded that the LNT model and its use for assessing the risks associated with low doses are not based on scientific evidence. In contrast, the Biological Effects of Ionizing Radiation (BEIR) VII report ${ }^{69}$ and that of the International Commission on Radiological Protection ${ }^{70}$ (ICRP) recommended the use of the LNT model for lack of a better approach. Professional societies such as the American Nuclear Society and the Health Physics Society also question the validity of assumptions of the LNT model. Furthermore, those potential thousands of cancers that might develop as a result of low dose radiation exposure are indistinguishable from the millions of cancers (according to estimates from the International Agency for Research on Cancer, there were 12.7 million new naturally occurring cancer cases in 2008 worldwide $^{71}$ ) that occur naturally or as a result of exposure to other chemical carcinogens. ${ }^{72}$ In other words, the number of cancers obtained with the LNT model is intrinsically unverifiable and the United Nations Scientific Committee on the Effects of Atomic Radiation observed that this terminology had caused "widespread misunderstanding among the general public, media, authorities and even scientists regarding the scale and nature of the health impact of the Chernobyl accident". ${ }^{73}$ Further research on the effects of low radiation doses is crucial to reach a consensus on this matter because the use of the LNT model has far reaching consequences such as on the decision to displace large populations following a nuclear accident for example.

To put the risk (real or perceived) associated with the use of nuclear energy in perspective, a recent publication from the World Health Organization (WHO) states that "air pollution is a major environmental risk to health" and that "outdoor air pollution in both cities and rural areas was estimated to cause 3.7 million premature deaths worldwide in 2012" ${ }^{74}$ Further, the specialized cancer agency of the WHO, the International Agency for Research on Cancer (IARC), announced recently that "it has classified outdoor air pollution 
as carcinogenic to humans" and that "the most recent data indicate that in 2010, 223,000 deaths from lung cancer worldwide resulted from air pollution". ${ }^{75}$ Such dire statements have only gained very limited political traction so far, probably because the public does not strongly protest against it.

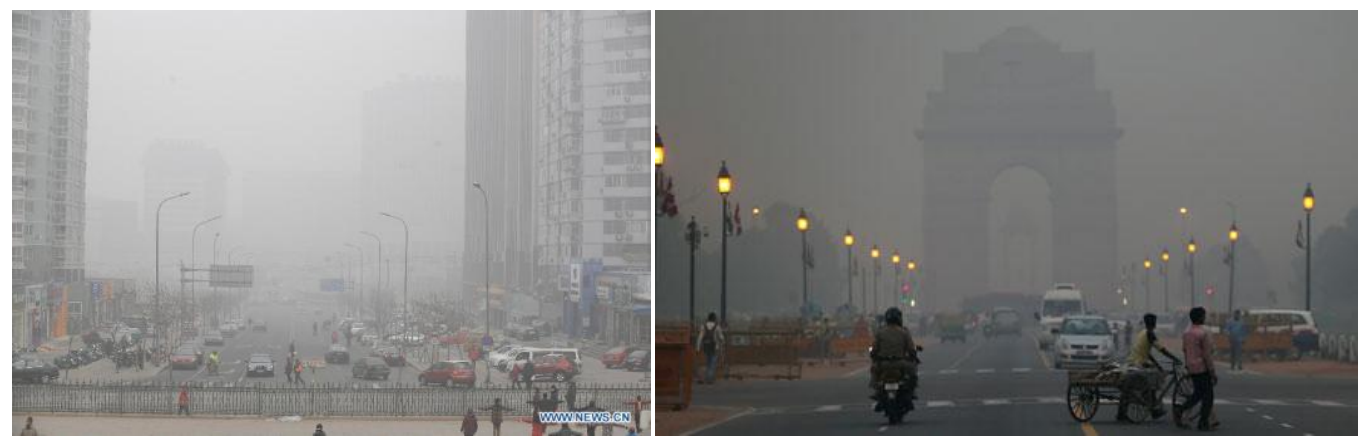

Left: Fog-enveloped Yinhe Street in Beijing, capital of China, Jan. 23, 2013 Source: http://www.china.org.cn/environment

Right: The India Gate monument in New Delhi, India, enveloped by a blanket of smog Source: http://www.theguardian.com/environment

Furthermore, whereas most of the general public will very likely point at the Chernobyl and Fukushima accidents as the worst modern science and engineering failures, only very few (if any) will remember the 1975 collapse of the Banqiao dam (China) where approximately 26,000 people died from flooding and another 145,000 died because of epidemics and famine. Another dam, Machchu-2, in India also failed a few years later (1979) killing at least 2,000 people. In 1984, a gas leak from a pesticide plant in Bhopal, India killed approximately 3,800 people and several thousand other individuals experienced permanent or partial disabilities.

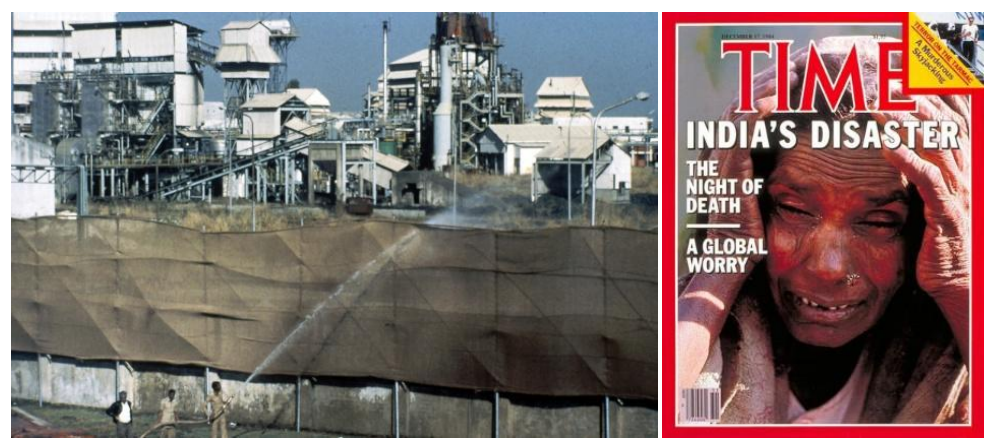

A gas leak from a chemical plant caused the Bohpal tragedy in December 3, 1984

Source: http://www.thehindu.com/

In 1988, an explosion and resulting fire on a North Sea oil production (Piper Alpha) platform killed 167 men. More recently, in 2008, the Koshi dam (Nepal) failed, killing 250 people and leaving nearly 100,000 people homeless. In 2009, an explosion at the SayanoShushenskaya hydraulic power station (Russia) killed 75 people. In 2013, the derailment of an oil shipment train at Lac-Mégantic (Canada) and the following explosion killed 47 people 
and a few months later, in China, an oil pipeline exploded in Huangdao, Shandong Province, killing 55 people. In 2014, an explosion at the Soma coal mine (Turkey) killed 301 miners and a few months later, in Taiwan, a natural gas pipe explosions in the city of Kaohsiung killed at least 30 people and injured over 300 .

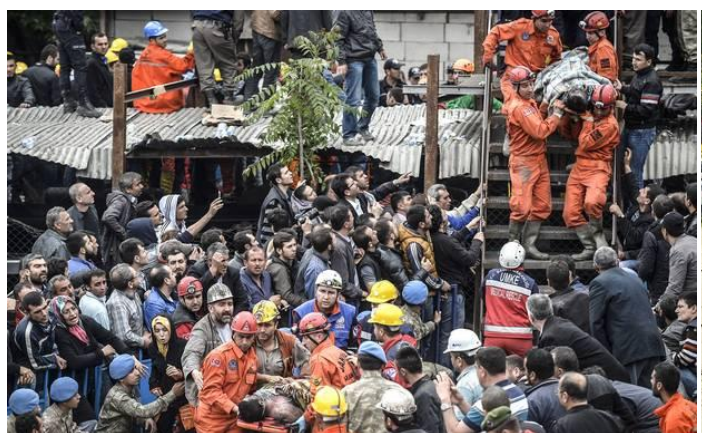

Soma coal mine disaster (2014)

Source: http://www.independent.co.uk/

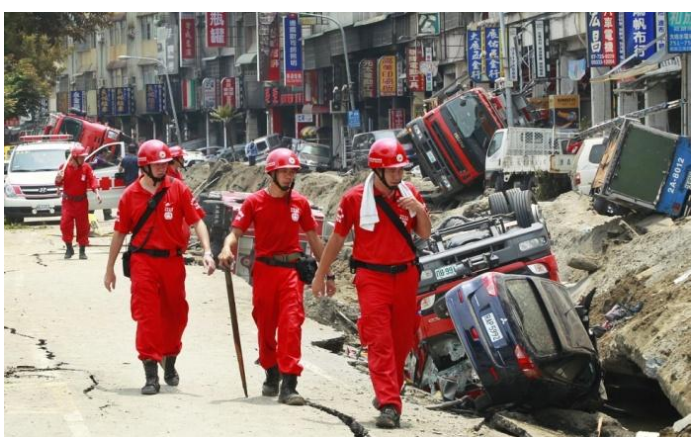

Gas explosion in the city of Kaohsiung (2014)

Source: http://www.scmp.com/news/china

The purpose of the above discussion is to emphasize that severe nuclear accidents such as Chernobyl and Fukushima have an important impact on populations because of relocation but that in terms of casualties they are less, or at least no more, catastrophic than other industrial accidents that have unfortunately plagued the energy sector. As mentioned earlier, until fusion power becomes a viable alternative, uranium used in fast breeder reactors (or in current reactors if it can be economically recovered from seawater) represents the largest source of concentrated low-carbon energy available to mankind. In a carbon constrained world it would make a lot of sense to greatly expand its use in conjunction with renewable energies and energy storage.

Finally a discussion on risks associated to nuclear energy must mention proliferation which has been a concern since the dawn of the nuclear era and will also probably play an important role in deciding its future. In general, assessing proliferation risk is a complex and challenging endeavor, primarily because it involves both technical and socio-political considerations, with the dominant factor being facility location. This issue must be carefully weighted and compared with the potential benefits that a well orchestrated expansion of nuclear energy could bring to the world, i.e. an essentially unlimited carbon-free energy source. 


\section{Conclusions}

The world electricity production, which was about 22 trillion $\mathrm{kWh}$ in 2011, is expected to reach 40 trillion $\mathrm{kWh}$ in 2040 and could be as high as 60 trillion $\mathrm{kWh}$ in 2100. If this increase is met mainly by coal and natural gas, in addition to quickly depleting these resources, the Intergovernmental Panel on Climate Change (IPCC) foresees a drastic climate change due to the $\mathrm{CO} 2$ emissions. Indeed, in order to limit the temperature increase to no more than $2^{\circ} \mathrm{C}$ by 2100 , the latest IPCC report urges that global $\mathrm{CO} 2$ emissions from the power sector should be reduced by 90 percent or more below 2010 levels between 2040 and 2070. Most of the technologies necessary to capture and store CO2 underground already exist but on a much smaller scale and the real challenge is to extrapolate them so that they are up to par with the actual size of the problem. Hence, reaching such an ambitious $\mathrm{CO} 2$ emission reduction target will most likely require greatly increasing the share of wind, solar and nuclear energy in the energy mix and doing this very quickly, i.e. in the next 40 to 50 years.

If wind and solar are to play an important role in reducing greenhouse gas emissions from the power sector (by, let's say, reducing them by a factor of 10 as suggested in the IPCC report), massive energy storage systems will be necessary. While many forms of energy storage have been installed, pumped hydro systems are by far the most widely used, with more than $127 \mathrm{GW}$ installed worldwide in 2010. Compressed air energy storage installations are the next largest $(0.44 \mathrm{GW})$, followed by sodium-sulfur batteries $(0.32 \mathrm{GW})$. Without storage, wind and solar can only have a limited impact on $\mathrm{CO} 2$ emissions as it will depend mainly on the energy mix used during wind and solar down time. Because of their intrinsic low power densities and capacity factors, wind and solar will require very large areas if they are to play a significant role in reducing greenhouse gas emissions. The large areas that are required would be challenging but not unrealistic as long as a solution for energy storage exists.

Nuclear energy has the advantage of being very concentrated and of not producing $\mathrm{CO} 2$ or other air pollutants during operation. If the totality of the current world electric production from coal, gas, oil and nuclear combined (17.6 trillion $\mathrm{kWh}$ ) came from current technology nuclear power plants alone, the uranium resources, which are currently estimated to be between about 8 and 24 million tonnes, could last between about 20 and 60 years. Hence, these power plants could not sustain such a capacity increase for very long unless the uranium resources are actually larger than current estimates and/or a cost-effective method of extracting uranium from seawater was available. If that was the case, current technology nuclear power plants could generate the equivalent of today electricity generated from coal, gas, oil and nuclear combined for about 10,000 years. To alleviate the need for natural uranium, several countries throughout the world have been actively pursuing the development of a different, more efficient, kind of nuclear reactor for decades: the fast breeder reactor. Using only conventional uranium resources (i.e. no uranium from seawater), fast breeder reactors could provide electricity safely and reliably for at least 3,000 years even if, alone, it had to produce the total current electrical power coming from coal, gas, oil and nuclear combined. Also worthwhile mentioning is that, even though the cost of a $1 \mathrm{GWe}$ nuclear power plant 
may be higher than that of a $1 \mathrm{GWe}$ wind or solar power plant, the investment necessary to implement a 100 percent wind and solar option would very likely be higher than that necessary to implement a 100 percent nuclear option because of the much larger number of GWe required.

Finally, considering the numerous industrial accidents that have resulted in fatalities as well as the effects of air pollution on human health, it can be argued that, despite the perception of a large fraction of the public and the media, severe nuclear accidents such as Chernobyl and Fukushima are no more catastrophic than other industrial accidents that have, unfortunately, plagued the energy sector. Severe nuclear accidents expose only very few people to high radiation doses but can on the other hand expose large populations to low radiation doses. Further research on the controversial effects of low radiation doses is crucial to reach a consensus on this matter because it has far reaching consequences such as on the decision to displace large populations following a nuclear accident for example. Until fusion power becomes a viable alternative, uranium used in fast breeder reactors (or in current reactors if it can be economically recovered from seawater) represents the largest source of concentrated low-carbon energy available to mankind. In a carbon constrained world it would make a lot of sense to greatly expand its use in conjunction with renewable energies and energy storage.

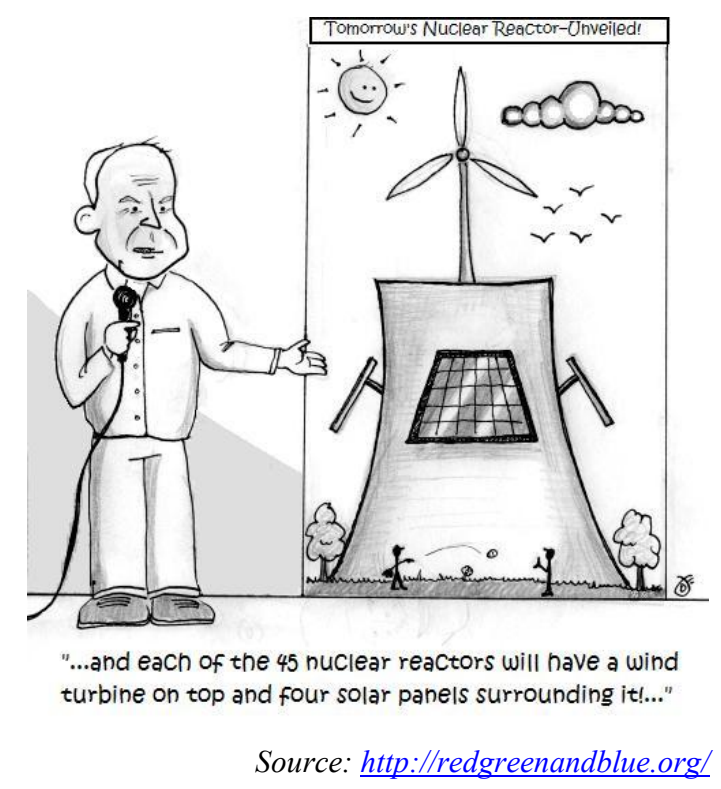




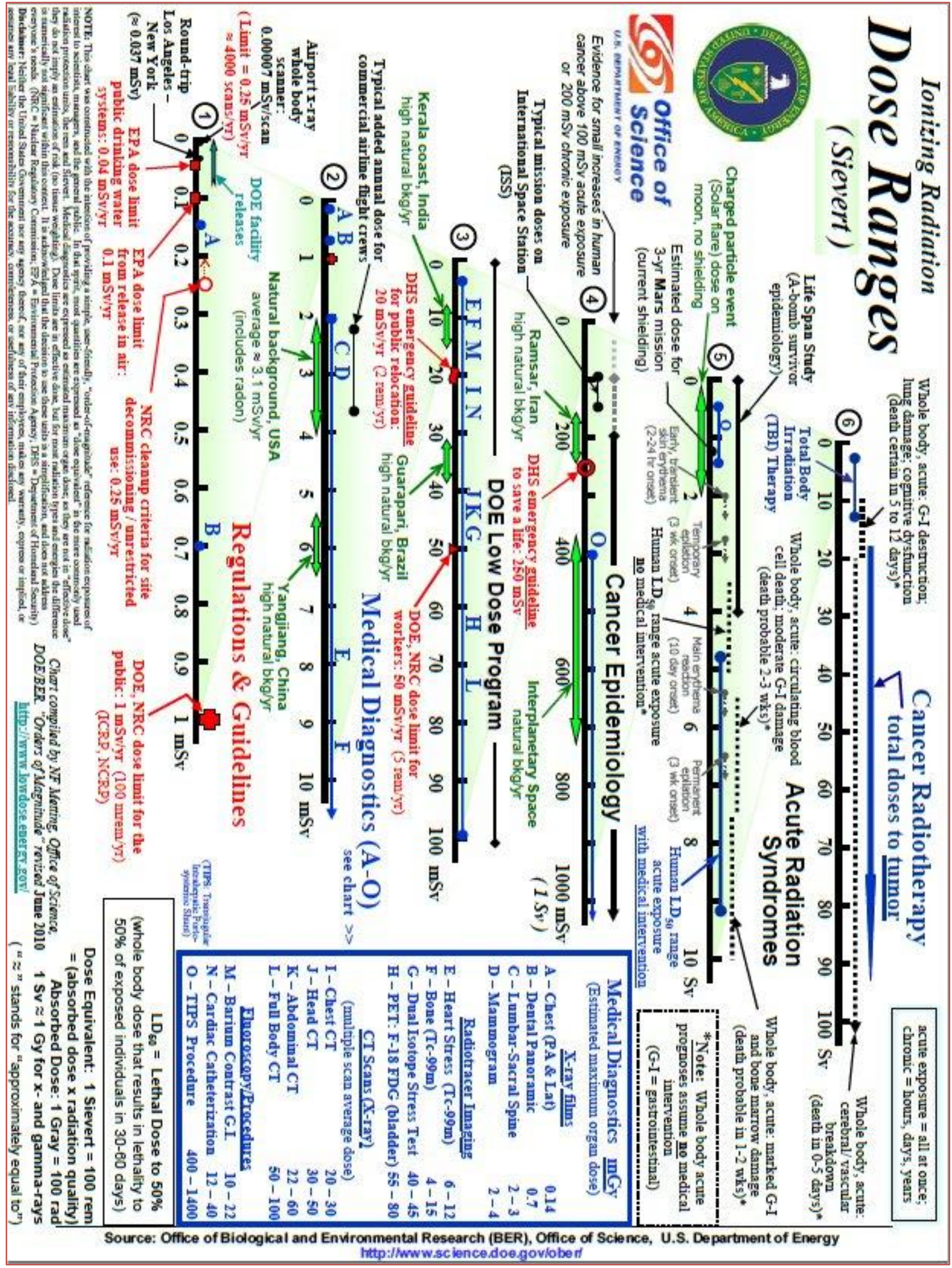




\section{References}

${ }^{1}$ International Energy Agency, "2013 Key World Energy Statistics"

${ }^{2}$ U.S. Energy Information Administration, "International Energy Outlook 2013"

${ }^{3}$ International Energy Agency, "CO2 Emissions From Fuel Combustion - Highlights (2013 Edition)"

${ }^{4}$ Intergovernmental Panel on Climate Change, Fifth Assessment Synthesis Report, Summary for Policymakers, Section SM-4.3 (2014)

${ }^{5}$ International Energy Agency, "Transport, Energy and CO2 - Moving Toward Sustainability” (2009)

${ }^{6}$ Electric Power Research Institute, “Consumer's Guide to Plug-In Electric Vehicles” (2014)

${ }^{7}$ Ball M. and Wietschel M., "The Hydrogen Economy - Opportunities and Challenges”, Cambridge University Press, 2009

${ }^{8}$ O'Brien J. E., "Review of the Potential of Nuclear Hydrogen for Addressing Energy Security and Climate Change", Nuclear Technology, Vol. 178 (2012)

${ }^{9}$ US Environmental Protection Agency, Office of Transportation and Air Quality, EPA-420-F-12-051 (2012)

${ }^{10}$ European Commission, "Reducing $\mathrm{CO} 2$ emissions from passenger cars", online information, http://ec.europa.eu/clima/policies/transport/vehicles/cars/index_en.htm

${ }^{11}$ United Nation Water Project, "Coping with water scarcity - Challenge of the twenty-first century”, 2007

${ }^{12}$ US National Research Council, "Desalination: A National Perspective", 2008

${ }^{13}$ United Nations Environment Program, "An Overview of the State of the World's Fresh and Marine Waters - 2nd Edition", 2008, http://www.unep.org/dewa/vitalwater/article42.html

14 “The Future of Coal", An Interdisciplinary MIT Study, 2007. Table 3.1 and 3.5 present coal consumption and CO2 emissions for various coal-fired power plants

${ }^{15}$ Electric Power Research Institute, “Coal ash: Characteristics, Management and Environmental Issues”, 2009

${ }^{16}$ US Congressional Research Service, "Regulating Coal Combustion Waste Disposal: Issues for Congress”, 2010

17 “Radioactive Elements in Coal and Fly Ash", USGS Fact Sheet FS-163-97, http://pubs.usgs.gov/fs/1997/fs163-97/FS163-97.pdf

${ }^{18}$ US Congressional Research Service, "Displacing Coal with Generation from Existing Natural Gas-Fired Power Plants", 2010

${ }^{19}$ World Energy Council, "World Energy Resources - 2013 Survey”, page 1.2

${ }^{20}$ World Energy Council, "World Energy Resources - 2013 Survey"; 210 trillion cubic meters of proved recoverable reserves (page 3.25) plus 340 trillion cubic meters of risked recoverable unconventional gas reserves, i.e. shale, hydrates, tight gas and coalbed methane (pages 3.67 and 3.69). Total $=550$ trillion cubic meter

${ }^{21}$ National Center for Policy Analysis, online data, http://www.ncpa.org/pub/ba656

22 “Carbon Dioxide Capture and Storage R\&D Roadmap”, DOE/NETL (2010)

${ }^{23}$ International Energy Agency, "CCS Retrofit - Analysis of the Globally Installed Coal-Fired Power Plant Fleet”, 2014

24 “Carbon Capture Technology Program Plan”, DOE Clean Coal Research Program, DOE/NETL (2013) 
${ }^{25}$ Kling, G. W. et al, “The 1986 Lake Nyos Gas Disaster in Cameroon, West Africa”, Science Vol. 236 (1987)

${ }^{26}$ World Energy Council, “World Energy Scenarios - Composing Energy Futures to 2050”, 2013, page 22

${ }^{27}$ International Energy Agency, “Technology Roadmap - Wind Energy”, 2013

${ }^{28}$ International Energy Agency, "IEA Wind - 2013 Annual Report", page 4

${ }^{29}$ Land-Use Requirements of Modern Wind Power Plants in the United States”, NREL/TP-6A2-45834

${ }^{30}$ International Energy Agency, "IEA Wind - 2013 Annual Report", Table 1, page 4 - Total installed capacity in IEA Wind member countries is $268.84 \mathrm{GW}$ for a total annual output of $541.7 \mathrm{TWh}$. From these two numbers it is concluded that the average capacity factor is $23 \%(541,700 / 268.84 \times 8760=0.23)$.

${ }^{31}$ U.S. Energy Information Administration, "Electric Power Monthly with Data for January 2015”, Table 6.7.B.

${ }^{32}$ Fraunhofer Institute for Solar Energy Systems, "Electricity production from solar and wind in Germany in 2013". Wind capacity is $32.513 \mathrm{GW}$. Total annual output is $47.2 \mathrm{TWh}$. From these numbers it is concluded that the average German capacity factors of wind is $16.5 \%$.

${ }^{33}$ European Photovoltaic Industry Association, “Global Market Outlook for Photovoltaic 2014-2018”, 2014

34 "Land-Use Requirements for Solar Power Plants in the United States", NREL/TP-6A20-56290 (2013)

${ }^{35}$ U.S. Energy Information Administration, "Electric Power Monthly with Data for January 2015", Table 6.7.B.

${ }^{36}$ Fraunhofer Institute for Solar Energy Systems, "Electricity production from solar and wind in Germany in 2013". Solar capacity is $35.651 \mathrm{GW}$. Total annual output is $29.7 \mathrm{TWh}$. From these numbers it is concluded that the average German capacity factors of solar is $9.5 \%$.

${ }^{37}$ International Energy Agency, “Technology Roadmap - Solar Photovoltaic Energy - 2014 Edition”, page 18 - Solar photovoltaic generated 160 billion $\mathrm{kWh}$ in 2013. Assuming that photovoltaic capacity increased linearly in 2013 from $100 \mathrm{GWe}$ to $139 \mathrm{GWe}$, the average capacity was about $120 \mathrm{GWe}$. From these numbers it is concluded that the average photovoltaic capacity factor of $15 \%$.

${ }^{38}$ US Nuclear Regulatory Commission, online data, http://www.nrc.gov/reading-rm/doccollections/nuregs/staff/sr1437/v1/part02.html, Table 2.1. As shown in this table about $65 \%$ of the installed capacity is located on sites that encompass 500 to 2000 acres $\left(2\right.$ to $\left.8 \mathrm{~km}^{2}\right)$. Larger land-use areas are associated with plant cooling systems that include reservoirs, artificial lakes, and buffer areas.

${ }^{39}$ US Congressional Research Service, “Energy-Water Nexus: The Energy Sector’s Water Use”, 2013

${ }^{40}$ US Congressional Research Service, “Energy's Water Demand: Trends, Vulnerabilities, and Management”, 2010

${ }^{41}$ Electric Power Research Institute, “Electricity Energy Storage Technology Options”, EPRI-1020676 (2010)

${ }^{42}$ International Energy Agency, "IEA Wind - 2013 Annual Report", page 37

43 "Representation of Solar Capacity Value in the ReEDS Capacity Expansion Model", NREL/TP-6A20-61182, page 14

${ }^{44}$ Barnes, S. and Levine, G., "Large Energy Storage Systems Handbook”, CRC Press, 2011

45 "Flexible Generation - Backing up Renewables", EURELECTRIC report, 2011

46 “DOE/EPRI 2013 Electricity Storage Handbook in Collaboration with NRECA”, SAND2013-5131

${ }^{47}$ Boyle, G., "Renewable Electricity and the Grid - The Challenge of Variability", published by Earthscan, 2007

48 “Nuclear Energy and Renewables: System Effects in Low-carbon Electricity Systems”, NEA-7056 (2012) 
49 "Nuclear Energy Today - Second Edition”, OECD/NEA report 6885, 2012, page 20

${ }^{50}$ World Health Organization, "Depleted Uranium - Sources, Exposure and Health Effects", 2001; US Environment Protection Agency, "Depleted Uranium - Technical Brief", EPA-402-R-06-011, 2006; Nuclear Energy Agency, "Management of Depleted Uranium”, 2001

${ }^{51}$ US Nuclear Regulatory Commission, online data, http://www.nrc.gov/waste/spent-fuel-storage/faqs.html

52 "Categorization of Used Nuclear Fuel Inventory in Support of a Comprehensive National Nuclear Fuel Cycle Strategy”, ORNL/TM-2012/308, FCRD-FCT-2012-000232

53 "Readiness of Existing and New U.S. Reactors for Mixed-Oxide (MOX) Fuel”, EPRI-1018896 (2009)

54 "Radioactive Waste in Perspective", NEA-6350 (2010)

55 “Uranium 2014: Resources, Production and Demand", NEA-7209 (2014). The total identified conventional resources are currently estimated at 7.6 million tonnes whereas the total undiscovered conventional resources (prognosticated resources and speculative resources) are estimated at 7.7 million tonnes. In addition to conventional resources the estimated total unconventional uranium resources (not including uranium in seawater) are currently estimated at 7.3 to 8.4 million tonnes.

56 "Status of Fast Reactor Research and Technology Development”, IAEA-TECDOC-1691

57 “Status and Trends in Spent Fuel Reprocessing”, IAEA-TECDOC-1467

${ }^{58}$ Gen IV International Forum, “Technology Roadmap Update for Generation IV Nuclear Energy Systems”, 2014

59 “TerraPower, LLC Traveling Wave Reactor Development Program Overview”, Proceedings of ICAPP 2013 conference, http://terrapower.com/uploads/docs/ICAPP_2013_Paper_FD226.pdf

${ }^{60}$ World Nuclear News, China plans for nuclear growth, November 19, 2014, http://www.world-nuclear-news.org/NPChina-plans-for-nuclear-growth-2011144.html

${ }^{61}$ World Nuclear Association, Nuclear Power in India, December 16, 2014. http://www.worldnuclear.org/info/Country-Profiles/Countries-G-N/India/

${ }^{62}$ U.S. Energy Information Administration, "Updated Capital Cost Estimates for Utility Scale Electricity Generating Plants", 2013

63 “2011 Cost of Wind Energy Review”, NREL/TP-5000-56266 (2013)

${ }^{64}$ UNSCEAR (2008), Report to the General Assembly with Scientific Annexes, Volume II, http://www.unscear.org/docs/reports/2008/11-80076_Report_2008_Annex_D.pdf

${ }^{65}$ UNSCEAR (2013), Report to the General Assembly with Scientific Annexes, Volume I, Scientific Annex A, http://www.unscear.org/docs/reports/2013/13-85418_Report_2013_Annex_A.pdf

${ }^{66}$ World Nuclear Association, "Nuclear Radiation and Health Effects", http://www.world-nuclear.org/info/Safety-andSecurity/Radiation-and-Health/Nuclear-Radiation-and-Health-Effects/

${ }^{67}$ World Nuclear Association, "Radiation and Life", http://www.world-nuclear.org/info/Safety-and-Security/Radiationand-Health/Radiation-and-Life/

${ }^{68}$ Tubiana M. et al, "Dose-effect relationships and the estimation of the carcinogenic effects of low doses of ionizing radiation", Academy of Medicine (Paris) and Academy of Science (Paris) Joint Report No. 2, March 30, 2005 
${ }^{69}$ US National Research Council, "Committee to Assess Health Risks from Exposure to Low Levels of Ionizing Radiation. Health risks from low levels of ionizing radiation: BEIR VII, Phase 2"

${ }^{70}$ International Commission on Radiological Protection. Low-dose extrapolation of radiation-related cancer risk. Publication 99. Amsterdam, the Netherlands: Elsevier,

${ }^{71}$ American Cancer Society, “Global Cancer Facts \& Figures - 2nd Edition”, 2011

${ }^{72}$ US Nuclear Regulatory Commission, Radiation exposure and Cancer, online data, http://www.nrc.gov/aboutnrc/radiation/health-effects/rad-exposure-cancer.html

${ }^{73}$ UNSCEAR (2008), Report to the General Assembly with Scientific Annexes, Volume II, page 56, http://www.unscear.org/docs/reports/2008/11-80076_Report_2008_Annex_D.pdf

${ }^{74}$ World Health Organization, “Ambient (Outdoor) Air Quality and Health”, Fact sheet N³13, Updated March 2014, http://www.who.int/mediacentre/factsheets/fs313/en/

${ }^{75}$ World Health Organization, “Outdoor Air Pollution a Leading Environmental Cause of Cancer Deaths”, Press Release 221, October 2013, http://www.iarc.fr/en/media-centre/iarcnews/pdf/pr221_E.pdf

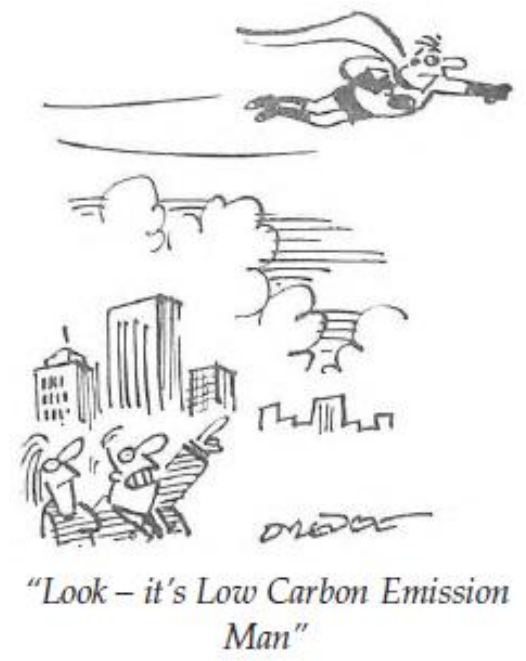

Source: $\underline{\text { www.private-eye.co.uk }}$ 